\title{
Productivity gains and spillovers from offshoring
}

March 2011

Bernhard Michel,bm@plan.be

\begin{abstract}
Offshoring is generally believed to be productivity-enhancing and this belief is underpinned by economic theory. This article contributes to the growing literature that tests empirically whether offshoring does indeed help to improve productivity. Estimating the impact of materials and business services offshoring on productivity growth with industry-level data for Belgium over the period 1995-2004, we investigate this issue separately for manufacturing and market services. The results show that there is no productivity effect of materials offshoring, while business services offshoring leads to productivity gains especially in manufacturing. In addition, we look at the possibility of rent spillovers from offshoring. Productivity gains from offshoring in one industry may feed through to other industries that purchase its output for intermediate use if, due to offshoring, the user value exceeds the price of the output. The lack of evidence of such rent spillovers from either materials or business services offshoring in the data leads us to conclude that firms manage to internalise all efficiency gains from offshoring.
\end{abstract}

Jel Classification - F14, F43, O33, O47

Keywords - offshoring, materials, business services, productivity, rent spillovers

With acknowledgement of the source, reproduction of all or part of the publication is authorized, except for commercial purposes. 



\section{Executive Summary}

The shift abroad of economic activities is a major issue for the empirical research on the risks and opportunities of an ever more integrated global economy. It has become common practice to measure the offshoring intensity through the share of imported intermediates in total nonenergy inputs as trade in intermediates mostly results from the transfer abroad of parts of an economic activity and hence reflects to a large extent the growing international fragmentation of production processes. This measure is mostly computed separately for materials and business services using data on intermediates from input-output tables or supply-and-use tables.

The overall welfare-enhancing character of offshoring is essentially driven by an improvement in productivity and, on theoretical grounds, there is little doubt regarding the productivity gains from offshoring. Nevertheless, given some practical caveats (underestimation of the costs of offshoring, reversal of the offshoring decision) it remains an empirical question whether productivity gains from offshoring do effectively materialise. A growing body of literature attempts to answer this question.

This article presents industry-level evidence on the impact of materials and business services offshoring on productivity for Belgium over 1995-2004 based on a constant price offshoring measure computed from a time series of supply-and-use tables. This is of particular interest as previous work has shown that offshoring has no impact on total industry-level employment in Belgium. Furthermore, it is one of the first article to investigate this issue separately for market service industries.

The results from including the offshoring intensities in production function estimations show that between 1995 and 2004 materials offshoring has no impact on productivity growth in either manufacturing or market services, while business services offshoring brings significant productivity gains in manufacturing. This is due to business services offshoring being an expanding phenomenon, whereas materials offshoring is mature and stagnating. We also split the offshoring intensities by region of origin of the imports. Introducing those splits in the estimations shows that the productivity gains from business services offshoring are due to offshoring to OECD countries rather than to low-wage countries.

Moreover, indirect productivity gains or spillovers from offshoring are taken into consideration. Indeed, productivity improvements through offshoring in a supplier firm or industry may feed through to buyer firms or industries that use the output of the former as input in their production process. There is scope for rent spillovers when the user value of the good or service exceeds its price, i.e. when firms fail to reap the full productivity gains from offshoring. However, the evidence on spillovers from offshoring in the data is so scarce and weak that we conclude that firms do indeed manage to internalise all efficiency gains from offshoring. In other words, rent spillovers are effectively prevented. 


\section{Synthese}

Delokalisatie (offshoring), het verhuizen van economische activiteiten naar het buitenland, is een belangrijk thema binnen het empirisch onderzoek naar de risico's en uitdagingen van een steeds meer geïntegreerde wereldeconomie. Het is gangbaar geworden om de offshoringintensiteit te meten aan de hand van het aandeel van de intermediaire invoer in de totale nietenergie input, omdat de handel in intermediaire goederen voornamelijk voortvloeit uit de overdracht van delen van een economische activiteit naar het buitenland en dus voor een groot deel de groeiende internationale fragmentatie van de productieketen weerspiegelt. Die maatstaf wordt meestal afzonderlijk berekend voor goederen en zakelijke diensten met behulp van gegevens over intermediair verbruik uit de input-outputtabellen of aanbod- en gebruikstabellen.

Het globaal welvaartsverhogende karakter van delokalisatie wordt in wezen gedreven door een verbetering van de productiviteit. Theoretisch beschouwd bestaat er weinig twijfel over de productiviteitswinsten verbonden aan delokalisatie. Niettemin, gezien enig praktisch voorbehoud (onderschatting van de kosten voor delokalisatie, herziening van de beslissing tot delokalisatie), blijft het een empirische vraag of die productiviteitswinsten effectief verwezenlijkt worden. Een groeiend aandeel van de literatuur probeert die vraag te beantwoorden.

In dit artikel wordt op bedrijfstakniveau de impact van de delokalisatie van goederen en zakelijke diensten op de productiviteit in België onderzocht voor de periode 1995-2004. Hierbij wordt een offshoring-maatstaf tegen constante prijzen gebruikt die gebaseerd is op een tijdreeks van aanbod- en gebruikstabellen. Dat is van bijzonder belang omdat voorgaande studies hebben aangetoond dat delokalisatie geen impact heeft op de totale werkgelegenheid op bedrijfstakniveau in België. Bovendien is dit een van de eerste artikels die dit thema voor de sector van de marktdiensten afzonderlijk bestuderen.

De resultaten van de integratie van de offshoring-intensiteit in de schatting van productiefuncties tonen aan dat tijdens de periode 1995-2004 de delokalisatie van goederen geen impact gehad heeft op de productiviteitsgroei in de verwerkende nijverheid en de sector van de marktdiensten, terwijl de delokalisatie van zakelijke diensten wel degelijk productiviteitswinsten heeft opgeleverd in de verwerkende nijverheid. Dat is te wijten aan het feit dat de delokalisatie van zakelijke diensten zich uitbreidt, terwijl de delokalisatie van goederen reeds is volgroeid en niet verder toeneemt. We delen de offshoring-intensiteit ook op per regio van herkomst van de invoer. Die opdeling geeft aan dat de productiviteitswinsten uit de delokalisatie van zakelijke diensten eerder afkomstig is van delokalisatie naar OESO-landen dan naar lagelonenlanden.

Daarenboven wordt er ook rekening gehouden met onrechtstreekse productiviteitswinsten of 'spillovers' van delokalisatie. Productiviteitsverbeteringen door delokalisatie in toeleveringsbedrijven of -industrieën kunnen doorstromen naar de aankopende bedrijven of industrieën die de output van die eerste groep gebruiken als input voor hun productieproces. Er is ruimte voor 
'rent spillovers' wanneer de gebruikswaarde van een goed of dienst zijn prijs overstijgt of, met andere woorden, wanneer bedrijven er niet in slagen de volledige winsten uit de delokalisatie te halen. Het bewijs voor het bestaan van spillovers van delokalisatie in de gegevens is evenwel zo schaars en zwak dat we kunnen besluiten dat bedrijven er inderdaad in slagen zich alle efficiëntiewinsten van delokalisatie toe te eigenen. Anders gezegd, 'rent spillovers' worden op een doeltreffende manier verhinderd. 


\section{Synthèse}

La délocalisation d'activités économiques est un sujet important pour la recherche empirique sur les risques et opportunités liés à l'intégration croissante de l'économie mondiale. Généralement, l'intensité des délocalisations est mesurée par la part des inputs intermédiaires importés dans le total des inputs intermédiaires hors énergie. En effet, le commerce de biens intermédiaires découle principalement de transferts d'activité à l'étranger et reflète dès lors, dans une large mesure, la fragmentation croissante des processus de production à l'échelle mondiale. Cette intensité de délocalisation est généralement calculée séparément pour les biens manufacturés et pour les services aux entreprises sur base de données qui proviennent des tableaux entrées-sorties ou des tableaux emplois-ressources.

Selon la théorie, les délocalisations entraînent une augmentation générale du niveau de bienêtre, principalement, grâce aux gains de productivité qui en résultent. Toutefois, étant donné certaines difficultés pratiques (sous-estimation du coût d'une délocalisation, réversibilité des décisions de délocalisation), il y a lieu de déterminer empiriquement si ces gains de productivité se concrétisent réellement. Cette question est de plus en plus abordée dans la littérature économique.

Le présent article contient des estimations de l'impact des délocalisations de biens manufacturés et de services aux entreprises sur la productivité au niveau des branches d'activité en Belgique pour la période 1995-2004. Une mesure des délocalisations à prix constants est calculée avec des données provenant d'une série temporelle de tableaux emplois-ressources. Ces estimations présentent un intérêt particulier car des travaux antérieurs tendaient à montrer que les délocalisations n'ont pas eu d'incidence sur l'emploi en Belgique. De plus, cette étude est parmi les premières à analyser cette question de façon distincte pour les services marchands.

La prise en compte de l'intensité de délocalisation dans les estimations de fonctions de production fait apparaître qu'entre 1995 et 2004 la délocalisation de biens manufacturés n'a d'impact sur la croissance de la productivité ni dans l'industrie manufacturière ni dans les services marchands, contrairement à la délocalisation de services aux entreprises qui entraîne des gains de productivité significatifs dans l'industrie manufacturière. Cette différence s'explique par le fait que la délocalisation de services aux entreprises est en plein essor alors que la délocalisation de la production de biens manufacturés est à maturité et tend à stagner. Nous avons également ventilé l'intensité des délocalisations par région d'origine des importations et introduit ces ventilations dans les estimations. Ceci révèle que les gains de productivité sont principalement générés par la délocalisation de services aux entreprises vers les pays de l'OCDE et non pas vers les pays à bas salaires.

En outre, les gains de productivité indirects des délocalisations, ou 'spillovers', sont pris en considération. Il s'agit des gains de productivité générés par des délocalisations de la part 
d'entreprises situées en amont d'un processus de production et qui se répercutent sur les entreprises ou branches d'activité qui, en aval, utilisent l'output de ces entreprises comme intrant. On parle de 'rent spillovers' lorsque la valeur d'usage d'un bien ou d'un service excède son prix, ce qui signifie que les entreprises qui délocalisent en amont ne parviennent pas à capter l'entièreté du gain d'efficience qui résulte de la délocalisation. Toutefois, les estimations montrent que les 'spillovers' sont faibles et presque jamais significatifs. Nous en concluons que les entreprises parviennent à internaliser l'entièreté des gains d'efficience de leurs délocalisations, évitant ainsi les rent spillovers. 


\section{Contents}

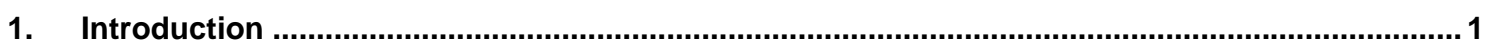

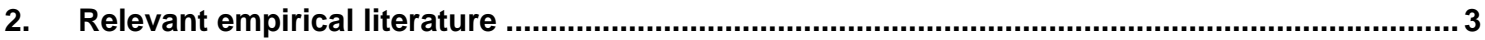

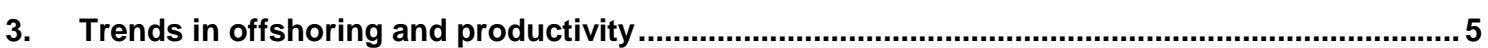

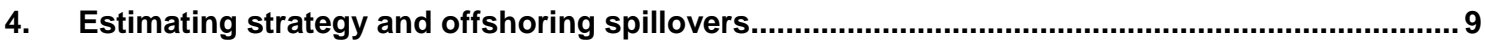

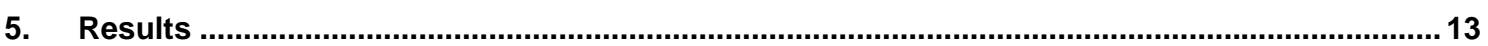

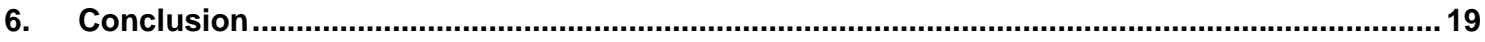

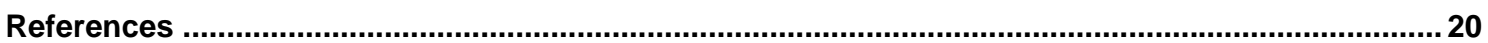

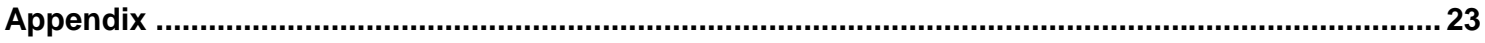




\section{List of tables}

$\begin{array}{lll}\text { Table } 1 & \text { Estimation results with total offshoring intensities in manufacturing } & 14\end{array}$

Table 2 Estimation results with total offshoring intensities in market services 15

Table 3 GMM-SYS estimation results with regional offshoring intensities in manufacturing 16

Table 4 GMM-SYS estimation results with regional offshoring intensities in market services 17

$\begin{array}{lll}\text { Table A1 List of industries, sut-code and description } & 23\end{array}$

$\begin{array}{llr}\text { Table A2 Data sources } & 25\end{array}$

$\begin{array}{ll}\text { Table A3 Descriptive statistics } & 25\end{array}$

Table A4 Estimation results for labour productivity (value-added per hour worked) with total and regional offshoring intensities in manufacturing

Table A5 Estimation results for labour productivity (value-added per hour worked) with total and regional offshoring intensities in market services

\section{List of figures}

Graph 1 Materials and business services offshoring in manufacturing 7

Graph 2 Materials and business services offshoring in market services $\quad 7$

Graph $3 \quad$ Value-added per hour worked in manufacturing and market services $\quad 8$

Graph A1 Year-on-year variations in value-added per hour worked and regional and overall materials offshoring in manufacturing

Graph A2 Year-on-year variations in value-added per hour worked and regional and overall business services offshoring in manufacturing

Graph A3 Year-on-year variations in value-added per hour worked and regional and overall materials offshoring in market services

Graph A4 Year-on-year variations in value-added per hour worked and regional and overall business services offshoring in market services

Graph A5 Average annual growth rates over 1995-2004 of value-added per hour worked and materials offshoring in 63 manufacturing industries

Graph A6 Average annual growth rates over 1995-2004 of value-added per hour worked and business services offshoring in 63 manufacturing industries

Graph A7 Average annual growth rates over 1995-2004 of value-added per hour worked and materials offshoring in $\mathbf{4 0}$ market service industries

Graph A8 Average annual growth rates over 1995-2004 of value-added per hour worked and business services offshoring in $\mathbf{4 0}$ market service industries 



\section{Introduction}

The shift abroad of economic activities is a major issue for empirical research on the risks and opportunities of an ever more integrated global economy. Initially called relocation, then international outsourcing or vertical specialisation, it is nowadays mainly referred to as offshoring. Its definition has been streamlined by international organisations (UNCTAD, 2004; WTO, 2005; OECD, 2007a), and since the pioneering work of Feenstra and Hanson (1996), it has become common practice to measure the offshoring intensity through the share of imported intermediates in total non-energy inputs. Indeed, trade in intermediates mostly results from transferring abroad parts of an economic activity and hence reflects to a large extent the growing international fragmentation of production processes. The initial measure of the offshoring intensity has been replicated by many authors, some of whom have put forward refinements and extensions: Feenstra and Hanson (1999) narrow offshoring, Egger et al. (2001) offshoring to low-wage countries, Amiti and Wei (2005) service offshoring. Almost all have used data on intermediates from input-output tables (IOT) or supply-and-use tables (SUT). OECD (2007b) provides a crosscountry comparison of the offshoring intensity, i.e. imported intermediates divided by total non-energy inputs, based on harmonised IOT for its member states. Singapore is top-ranked with an intensity above $40 \%$ in 2000 followed by Luxemburg and Ireland. Belgium stands seventh with an intensity slightly above $30 \%$. The latter result is confirmed in Michel (2008) who takes a look at offshoring measures for Belgium.

Beyond measurement, researchers have tried to understand the implications of offshoring for developed countries. From a theoretical point of view, the standard reasoning as set forth in Bhagwati et al. (2004) and Deardorff (2006) is that offshoring is essentially a trade phenomenon and that its impact can be explained through standard trade theory. Hence, offshoring is generally believed to be overall welfare-enhancing even though some authors, e.g. Samuelson (2004) or Kohler (2004) put forward conditions under which welfare losses through offshoring may occur for a country. Nonetheless, in line with traditional trade theory, the main downside of offshoring is its redistributive effect: certain categories of workers tend to lose out in terms of wages and employment - essentially low-skilled workers. This issue is largely covered in the literature as documented by two literature reviews (Hijzen, 2005; Crino, 2009). The results show that there is little or no impact of offshoring on overall employment, but that it entails a fall in relative employment or relative wage losses for low-skilled workers.

The overall welfare-enhancing character of offshoring is essentially due to an improvement in productivity and, on theoretical grounds, there is not much doubt regarding the productivity gains from offshoring. Amiti and Wei (2006) and Cheung et al. (2008) identify several channels through which offshoring may lead to productivity gains. First and foremost, such gains may be expected from a change in the composition of a firm's activities since firms will normally offshore less efficient parts of their production process to concentrate on more productive core activities. Second, less costly offshored inputs free up resources that can be used for productivity- 
enhancing investment into the remaining core business. Third, this goes hand in hand with efficiency gains from restructuring the production process in the wake of an offshoring decision. Finally, offshored inputs may also be of higher quality or greater variety thereby boosting productivity in the production stages still performed by the firm. In practice, these channels prove difficult to distinguish. They refer to what should be called the direct productivity gains from offshoring. But indirect productivity gains from offshoring should also be taken into consideration. Indeed, productivity improvements through offshoring in a supplier firm or industry may feed through to buyer firms or industries that use the output of the former as input in their production process. This amounts to productivity spillovers from offshoring, which means that the social return from offshoring exceeds the private return.

Nevertheless, some caveats should be mentioned. Firms may sometimes not be able to reap the productivity benefits from offshoring. Restructuring subsequent to an offshoring decision may take more time than foreseen and therefore productivity gains will only materialise with a lag. The cost of offshoring may also be underestimated. Worse, in some cases offshoring may fail, be reversed, and productivity gains from this source may be precluded. Hence, the issue of whether offshoring does indeed give rise to productivity gains as expected based on theory deserves to be investigated empirically. This has been done in several papers. Quite a few find evidence of productivity gains from offshoring (e.g. Egger et al., 2001, Amiti and Wei, 2009), but some fail to do so (e.g. Daveri and Jona-Lasinio, 2008). Furthermore, it is not clear whether these gains are more important for materials or services offshoring. There are also data issues: the analysis is focused on manufacturing industries and almost all papers use a current price offshoring measure. Moreover, none of those papers distinguishes between the channels through which offshoring enhances productivity. Last but not least, we are not aware of a paper that looks into the possibility of productivity spillovers from offshoring.

The aim of this paper is threefold. First of all, we want to determine whether there are productivity gains from offshoring for Belgium and estimate their size based on a constant price offshoring measure. This is of particular interest given the above-mentioned size of offshoring for Belgium and the fact that Michel and Rycx (2010) find that offshoring has no impact on total employment in Belgium. In this context, we check whether it is materials or service offshoring that leads to productivity gains and whether these gains are driven by offshoring to high-wage countries or to low-wage countries. Moreover, we specifically extend the analysis to service industries, which has rarely been done in the literature so far. Second, we want to contribute to the ongoing debate about the determinants of total factor productivity growth in Belgium (Biatour and Kegels, 2008) and find out whether offshoring is one of those determinants. Third, it is our aim to add to the literature by taking productivity spillovers from offshoring into account.

This paper is organised as follows. Section 2 provides an overview of the empirical literature, while trends in offshoring and productivity for Belgium are presented in section 3 . Then, section 4 describes the estimation strategy for determining productivity gains and spillovers from offshoring. Section 5 presents the results and section 6 the conclusion. 


\section{Relevant empirical literature}

In comparison with the mass of papers on the employment effect of offshoring, the literature on the impact of offshoring on productivity is relatively scarce but growing. Both reviews of the literature on this subject - Olson (2006) and Cheung et al. (2008) - remain cautious in their conclusions owing to the fact that relatively little empirical work has been done so far.

Several papers have attempted to measure the magnitude of productivity gains from offshoring at the industry level. They have done this by introducing offshoring as a technology shifter in a Cobb-Douglas production function and they have estimated its log-linear impact on total factor productivity (TFP) growth or on labour productivity growth. All of them use an offshoring intensity measure that corresponds to imported intermediates divided by total non-energy intermediates. It is computed by industry with data from IOT.

The earliest paper we are aware of is Egger et al. (2001). These authors show that materials offshoring to Eastern Europe has a positive significant impact on TFP growth for a panel of 20 manufacturing industries in Austria in the nineties. Then, Amiti and Wei $(2006,2009)$ report results on the impact of materials and services offshoring on TFP and on labour productivity for more than 90 US manufacturing industries between 1992 and 2000: services offshoring has a significant and sizeable positive impact, while the impact of materials offshoring is also positive but much smaller and only significant in some specifications. Similar results are put forward by Winkler (2010) for German manufacturing: in a sample of 33 industries over 1995-2006 services offshoring proves to be productivity-enhancing, whereas materials offshoring does not. This pattern is inverted in the results put forward in Daveri and Jona-Lasinio (2008). Covering the period 1995-2003 for 21 Italian manufacturing industries, they find that materials offshoring leads to a significant increase in TFP growth, whereas service offshoring does not. In a recent paper for Japan, Ito and Tanaka (2010) split the offshoring intensity by region: using data for about 50 industries for the years 1988 to 2004, they find that materials offshoring to Asian countries has a positive impact on TFP for Japanese manufacturing. They also show that service offshoring in Japanese manufacturing is at a low level and without any impact on TFP or labour productivity. Two further papers present a cross-country analysis. Egger and Egger (2006) use a CES production function and focus on the productivity of low-skilled workers. Based on data for twelve EU member states and 20 manufacturing industries for 1993-1997, they show that labour productivity of low-skilled workers first declines in the wake of offshoring and that the impact turns positive only at a later stage. In his analysis for 20 industries in nine EU member states for the years 1990-2004, Crino (2008) finds substantial TFP gains from a rather broad measure of service offshoring. The gains from materials offshoring turn out to be much lower.

There are also a few papers that take a look at productivity gains from offshoring with firmlevel data. Görg and Hanley (2005) and Görg et al. (2008) both use a plant-level dataset for Ireland covering, respectively, twelve sub-sectors of electronics, and all of manufacturing. Both 
measure offshoring as imported intermediates divided by either total inputs or the total wage bill and they distinguish between materials and services inputs, which is in line with the offshoring intensity measure of the industry-level papers. Surprisingly, the two papers report to some extent opposing results. Görg and Hanley (2005) find that only materials offshoring has a significant impact on TFP for low-export plants in the electronics industry over the period 19901995, whereas in the preferred specification of Görg et al. (2008) only services offshoring of high-export plants has a significant impact on TFP for the manufacturing sector as a whole over the period 1990-1998. Criscuolo and Leaver (2005) estimate the productivity gains from services offshoring for UK manufacturing and service sector firms between 2000 and 2003. They measure services offshoring as imports of services over total purchases of services and show that it has a positive significant impact on TFP. Furthermore, in their attempt to identify the channels through which offshoring impacts on firm-level employment, Moser et al. (2009) apply a propensity score matching approach to estimate whether firms that offshore are more productive than their counterparts that do not. They find positive evidence of this for a sample of German firms for the years 2000 to 2004. Finally, Hijzen et al. (2010) estimate the impact of total offshoring and intra-firm offshoring of materials on TFP growth in Japanese manufacturing over 19901994. According to their results, only the latter, i.e. intra-firm offshoring, fosters TFP growth.

To sum things up, most of the empirical evidence indicates that there are indeed productivity gains through offshoring, although it remains unclear whether materials or services offshoring is the driving force behind these gains. Apparently, this depends on country characteristics (Ito and Tanaka, 2010). So far, the literature has focused on manufacturing industries. Only Criscuolo and Leaver (2005) have looked at the impact of offshoring on productivity for service sector firms. ${ }^{1}$ Moreover, there are shortcomings in the offshoring intensity measures used, which are likely to result in an underestimation of the extent of offshoring. Finally, the papers have neither been able to distinguish between the above-mentioned channels through which offshoring leads to productivity gains, nor have they looked at productivity spillovers from offshoring in supplier industries.

Crino (2008) also includes a few service industries in his sample, but the impact of offshoring on those service industries is not examined separately. A single production function is estimated for manufacturing and service industries, which implies imposing the rather strong restriction of identical elasticities for all inputs in all industries. 


\section{Trends in offshoring and productivity}

Given the scarcity of direct measures of offshoring, the proxy measure pioneered by Feenstra and Hanson (1996) has become widely used. It amounts to taking the industry-level share of imported intermediates in total non-energy inputs as an indirect indicator of the extent of crossborder fragmentation of production processes in an industry, i.e. its offshoring intensity. For industry $i$ and year $t$, this can be written as

$o m_{i t}=\sum_{j=1}^{J^{\prime}} I_{i j t}^{m} / I_{i t}^{n e}$

where om stands for materials offshoring, Im for imported intermediate inputs, Ine for nonenergy intermediate inputs and $\mathrm{j}$ is the product index covering materials from 1 to $\mathrm{J}^{\prime}$, i.e. for materials offshoring, only imported intermediate materials are taken into account. The standard offshoring intensity definition was limited to materials until Amiti and Wei (2005) introduced service offshoring. Again for industry $i$ and year $t$, this is written as

$O S_{i t}=\sum_{j=J^{\prime}+1}^{J} I_{i j t}^{m} / I_{i t}^{n e}$

where os stands for service offshoring $\mathrm{j}$ is the product index covering services from $\mathrm{J}^{\prime}+1$ to $\mathrm{J}$. Normally, this is narrowed down to the category of business services, which are information technology and communication (ICT) services as well as other business services such as accounting or call centres. These kinds of services have become increasingly tradable and hence 'offshorable' in the wake of trade liberalisation and technological developments. Both om and os are usually computed with data from input-output tables (IOT). ${ }^{2}$ Following Egger et al. (2001), these offshoring intensities can be split by region according to the geographic origin of the imported intermediates so as to proxy for offshoring to high-wage countries and to lowwage countries. Materials offshoring to region $r$ can, for example, be defined as

$o m_{-} r_{i t}=\sum_{j=1}^{J^{\prime}} I_{i j t}^{m_{-} r} / I_{i t}^{n e}$

where suffix_r indicates the region of origin of the imports. For the purpose of computing such regional offshoring intensities, the data from IOT are complemented with detailed import data by country of origin.

2 By this we mean product by product IOT. However, a few papers, e.g. Amiti and Wei (2005) use supply-and-use tables (SUT) instead. The latter contain data on the use of goods and services by product and by type of use - final or intermediate by industry. They are part of the national accounts and the basis for constructing analytical IOT. 
Despite the widespread use of the measure, several caveats ought to be put forward. First of all, it should be kept in mind that om and os are indirect measures of offshoring as emphasized in OECD (2007a). Approximating the shift of activities abroad, i.e. offshoring through imported intermediates implies, on the one hand, leaving out cases where production for final demand is shifted abroad as well as cases where offshoring does not lead to imports of intermediates, and, on the other hand, taking into account some imports of intermediates that do not result from the shift abroad of an activity. Second, the volume of imported intermediates is frequently computed indirectly by multiplying total purchases of product $j$ (as intermediate) by industry $i$ with the share of imports in the total supply (imports and domestic output) of product $j$. This amounts to a rather restrictive assumption. Third, several drawbacks regarding the IOT used in most papers have to be pointed out: they are mostly available only every five years (reference years), in current prices and for different national accounts (NA) vintages.

In this paper, we compute offshoring intensities for Belgium on the basis of the same dataset as in Michel and Rycx (2011) updated and extended so as to cover the years 1995-2004. It contains constant price supply-and-use tables (SUT) that are consistent with the 2007 vintage of the Belgian NA. ${ }^{3}$ They contain an industry and product breakdown of approximately 120 industries and 320 products. We limit the dataset in terms of industries to the 103 private sector industries listed in Appendix Table A1. Imported intermediates have been computed according to the original methodology described in van den Cruyce (2004) for the reference years 1995 and 2000 and interpolated and extrapolated for the other years based on their share in total purchases of intermediates. It is straightforward to compute offshoring of materials (non-energy manufactured goods) and business services from this dataset according to the specifications above. Finally, we combine these data with detailed import data by country of origin to compute offshoring intensities for three regions: 22 OECD Member States ${ }^{5}, 10$ Central and Eastern European Countries $^{6}$, and 10 Asian countries $^{7}$. To identify these regional offshoring intensities, we use as suffix respectively _oecd,_ceec and _asia. The remainder of the overall offshoring intensities om and os is labelled by suffix _rest.

The results for the overall materials and business services offshoring intensities for the period 1995-2004 are shown in Graphs 1 and 2 for manufacturing industries and market service industries respectively. ${ }^{8}$ The intensity of materials offshoring in manufacturing stands at the rather high level of about $36 \%$, but stagnates over the whole period, while business services offshoring, starting from a very low level of $0.6 \%$, grows steadily and more than doubles between 1995

3 The initial construction and compilation method of these SUT is described in Avonds et al. (2007).

4 The split of the total offshoring intensity by region is done proportionally, i.e. by making the assumption for each product that the geographic distribution of imports is identical in all uses. The data on the geographic distribution of imports come from Intrastat and Extrastat for goods and from the balance of payments for services.

5 Austria, Australia, Canada, Denmark, Finland, France, Germany, Greece, Iceland, Ireland, Italy, Japan, Luxemburg, the Netherlands, New Zealand, Norway, Portugal, Spain, Sweden, Switzerland, the United Kingdom and the United States.

6 Bulgaria, the Czech Republic, Estonia, Hungary, Latvia, Lithuania, Poland, Romania, the Slovak Republic and Slovenia.

China, Hong Kong, India, Indonesia, Malaysia, the Philippines, Singapore, South Korea, Thailand and Taiwan.

8 Note that we have included construction industries in manufacturing. 
and 2004. In the market service industries, the materials offshoring intensity rises from $7.9 \%$ in 1995 to $10 \%$ in 2004 due to a sustained growth period between 1997 and 2001. Business services offshoring again stands at a lower level - 3.4\% in 1995 - but grows more steadily and faster to reach $5.7 \%$ in 2004. Regarding the regional splits, both the materials and the business services offshoring intensities are highest for the OECD region, while offshoring to the CEEC region is the most dynamic in terms of growth.

\section{Graph 1 Materials and business services offshoring (om and os) in manufacturing}
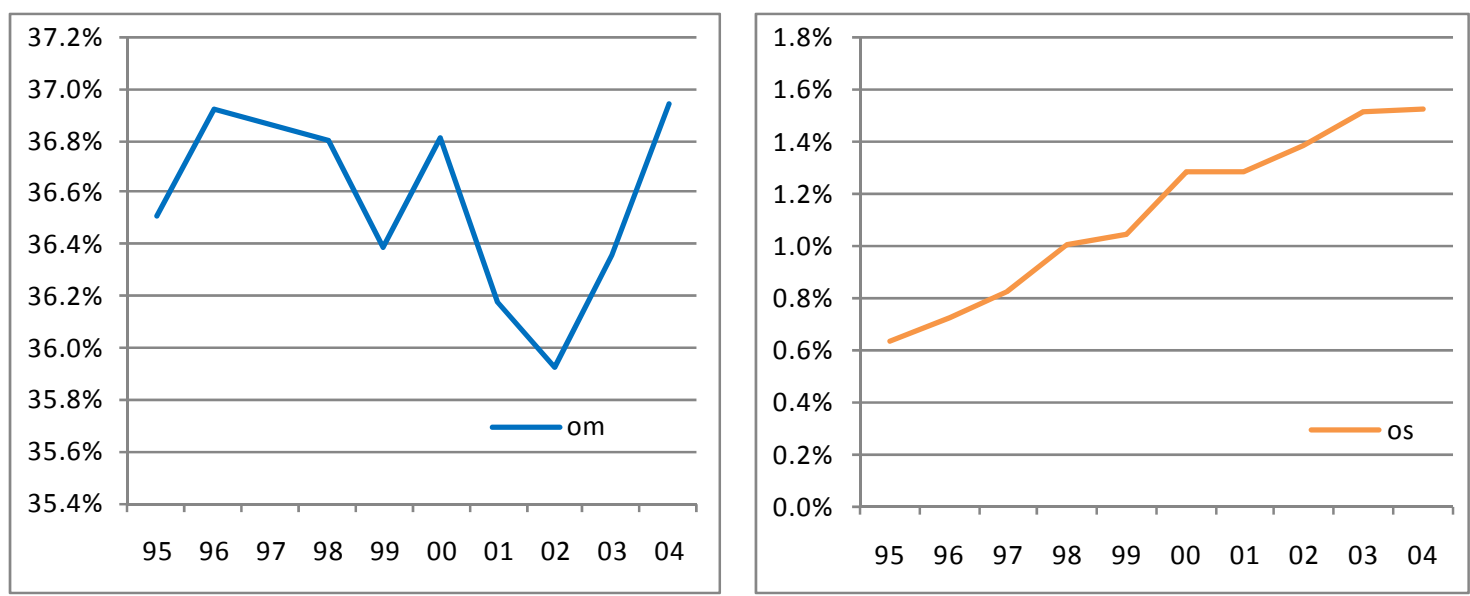

Source: own calculations

\section{Graph 2 Materials and business services offshoring (om and os) in market services}
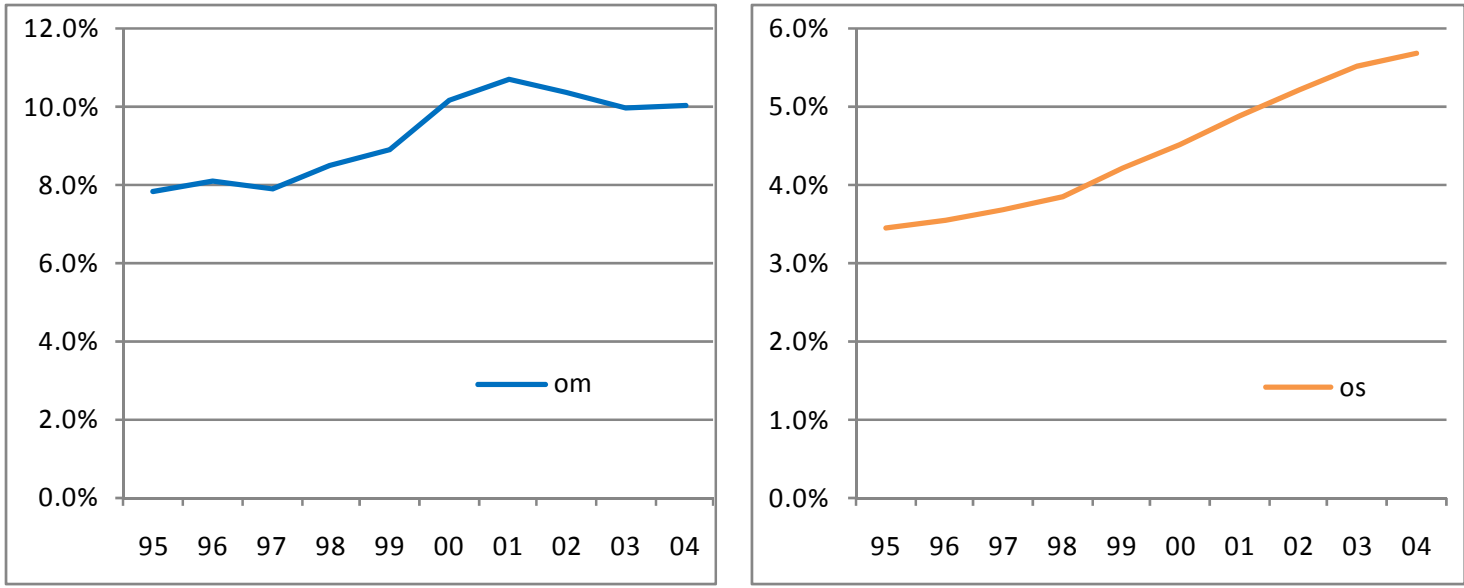

Source: own calculations

To give the reader a flavour of productivity trends for Belgium between 1995 and 2004, data on value-added per hour worked (labour productivity) are reported in Graph 3 for manufacturing and market services. In terms of levels, value-added per hour worked is higher in manufacturing over the entire period. Moreover, labour productivity growth is faster on average in manufacturing despite the significant acceleration in market services from 2001 onwards. The average 
labour productivity growth rates in our data are comparable to those reported in Biatour and Kegels (2008) for the years 1995-2005. ${ }^{9}$

\section{Graph 3 Value-added per hour worked in manufacturing and market services}
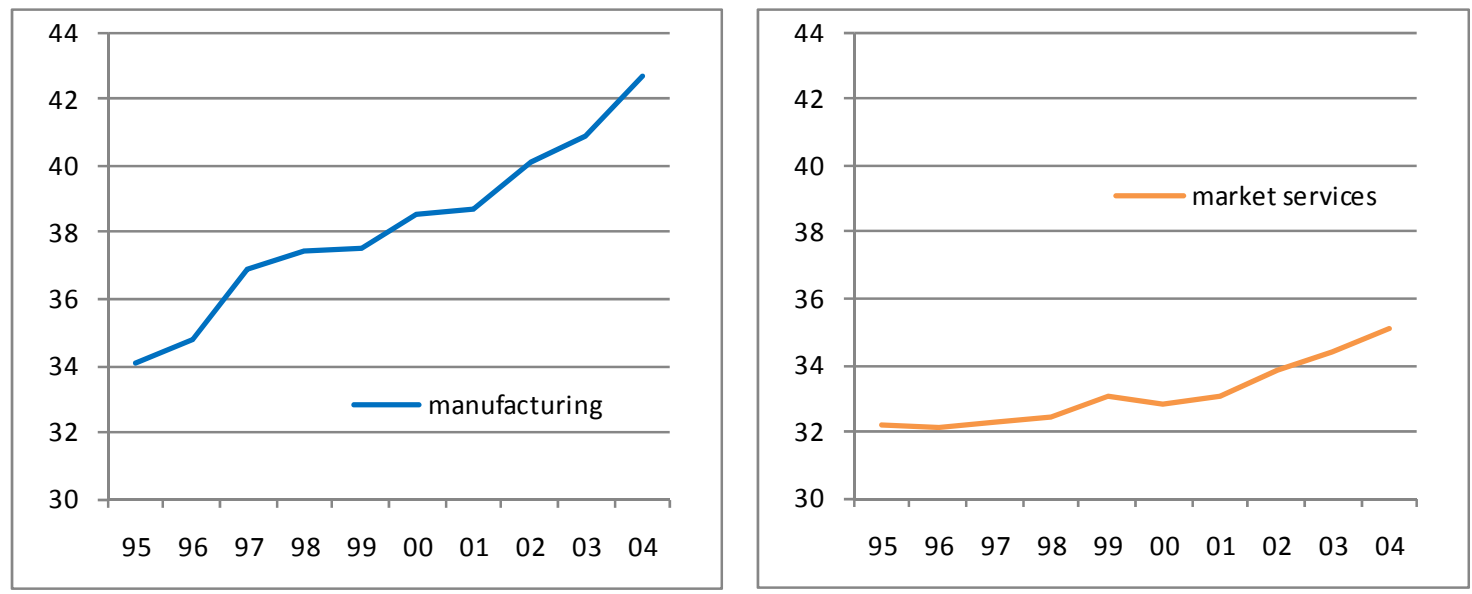

Source: own calculations

Four graphs in the Appendix (Graphs A1 to A4) show year-on-year variations in om and os for manufacturing and market services decomposed into contributions from the three abovementioned regions (_oecd,_ceec,_asia) as well as the remaining countries (_rest) and compare them to year-on-year variations in labour productivity (value-added per hour worked). There appears to be a positive correlation between changes in labour productivity and changes in the offshoring intensity for materials and business services in manufacturing and for business services in market service industries. This is confirmed by the scatterplots in the Appendix (Graphs A5-A8). They link the average growth rates over 1995-2004 of value-added per hour worked and om and os by industry, manufacturing and market services being separated as usual. There is again evidence of a positive relationship between os and labour productivity in both manufacturing and market services and between om and labour productivity in manufacturing only. ${ }^{10}$ Although these links do not imply any kind of causality and the next sections focus mainly on total factor productivity (TFP), comparing growth in offshoring and growth in labour productivity provides preliminary insights into whether offshoring may influence productivity growth.

9 In manufacturing, value-added per hour worked grows on average by $2.5 \%$ per year over $1995-2000$ and by $2.6 \%$ over 2000-2004, while in market services average value-added per hour worked growth amounts to $0.4 \%$ per year over 1995-2000 and 1.7\% over 2000-2004. Although the basic data is the same, differences with respect to the results in Biatour and Kegels (2008) are explained by differences in the aggregation procedure, the inclusion of construction industries in manufacturing and the fact that our dataset ends in 2004 rather than 2005.

10 The correlation coefficients between labour productivity and offshoring are 0.03 for om in manufacturing, 0.19 for os in manufacturing, -0.41 for om in market services and 0.15 for os in market services. However, only the negative correlation coefficient between labour productivity and os in market services is significant at the 5\%-level. 


\section{Estimating strategy and offshoring spillovers}

To determine the impact of industry-level offshoring on productivity, we adopt the standard production function approach as done in most of the related literature (e.g. Egger et al., 2001, Görg and Hanley, 2005, and Amiti and Wei, 2009). Output $Y$ of industry i during year $t$ is linked to inputs capital (K), labour (L), energy (E), materials $(\mathrm{M})$ and services (S) through the production function $\mathrm{F}$ and technology parameter $\mathrm{A}$ that corresponds to total factor productivity (TFP).

$Y_{i t}=A\left(o m_{i t}, o s_{i t}\right) F\left(K_{i t}, L_{i t}, E_{i t}, M_{i t}, S_{i t}\right)$

Materials and business service offshoring om and os are introduced as technology shifters, i.e. as determinants of the Hicks-neutral technological change term A. This encompasses all of the above-mentioned channels through which offshoring may lead to productivity gains.

To estimate the impact of the offshoring variables on TFP, we specify $\mathrm{F}$ to be a Cobb-Douglas production function and adopt the so called econometric approach to productivity measurement (see OECD, 2001) rather than growth accounting as in Biatour and Kegels (2008). The econometric approach seems more appropriate given the relatively limited time span of the data we use. Taking natural logs (ln) and first differences (d), we can write the estimating equation.

$$
\begin{aligned}
d \ln Y_{i t}= & \alpha+\beta_{k} d \ln K_{i t}+\beta_{l} d \ln L_{i t}+\beta_{e} d \ln E_{i t}+\beta_{m} d \ln M_{i t}+\beta_{s} d \ln S_{i t} \\
& +\beta_{o m} d_{o m}+\beta_{o s} d_{o s}+\gamma_{i} D_{i}+\gamma_{t} D_{t}+\varepsilon_{i t}
\end{aligned}
$$

The econometric approach implies constraining the $\beta$ parameters to be the same for all industries. This is the downside of the flexibility of the econometric approach compared to growth accounting.

The estimating equation (2) allows to measure the impact of the offshoring variables on TFP growth through the inclusion of the differenced levels of the offshoring intensities domit and dosit. First differencing eliminates time-invariant industry-level fixed effects in the equation in levels. The time dummies $\left(\mathrm{D}_{\mathrm{t}}\right)$ are included to account for time-specific shocks common to all industries, while the industry dummies $\left(\mathrm{D}_{\mathrm{i}}\right)$ control for the fact that some industries may have structurally higher growth rates over the whole period.

The main econometric problems that have to be addressed in this specification relate to the potential endogeneity of several regressors. OLS regressions of equations such as (2), based on output and the variable input factors energy, materials and services typically suffer from endogeneity as productivity may contemporaneously affect the choice of the level for the variable inputs. Two ways of tackling this problem are put forward in Amiti and Wei (2009). The first is to estimate an alternative TFP growth equation based on value-added per worker or hour 
worked. In this less rich specification, the variable input factors energy, materials and services are eliminated and the endogeneity problem is avoided. ${ }^{11}$ The results for the impact of the offshoring variables have to be compared in the two specifications. The other possibility to overcome this potential endogeneity is to estimate (2) using the GMM-method developed in Arellano and Bond (1991) - GMM-DIF. It is based on the use of lags of regressors as instruments. This may be extended to applying the GMM-SYS method developed in Blundell and Bond (1999), which simultaneously estimates the equation in first differences and in levels relying respectively on lagged levels and on lagged first differences as instruments.

Another potential endogeneity issue may result from the self-selection of the most productive firms into offshoring. Although there are indeed good reasons to believe that offshoring will foster productivity, many authors also stress that the most productive firms are the most likely to offshore parts of their production. This leads to reverse causality. Moreover, as pointed out in Görg et al. (2008), we may also observe the opposite, i.e. that in search of a survival strategy, low productivity firms systematically choose offshoring. This potential endogeneity problem is particularly important in the case of firm-level data and may to some extent be mitigated by aggregation, i.e. for industry-level data. There are three further possible remedies. First, there is the possibility of lagging the offshoring variables. Second, if the endogeneity between productivity and offshoring is time-invariant, then industry-specific dummies can take care of the problem, but this is probably true only over rather short periods. Third, the problem may again be tackled by relying on GMM-DIF and GMM-SYS methods.

Potential productivity gains from offshoring are measured by the coefficients $\beta_{\mathrm{om}}$ and $\beta_{\mathrm{os}}$ in equation (2). They reflect the direct impact of offshoring on TFP growth or, to put it differently, they allow to compute the private return to offshoring. However, if offshoring increases productivity in industry $j$, then this may affect productivity in industry i through the output of industry $j$ that is being used as intermediate input in industry $i$. Hence, a productivity spillover from industry $j$ to industry $i$ that is driven by offshoring may occur through input purchases by $i$ from $j$. As a consequence of such spillovers, the social return to offshoring would exceed the private return.

In the literature on productivity spillovers from R\&D expenditure, the type of spillovers that are brought about by purchases of intermediates has been dubbed 'rent spillovers' (Griliches, 1992). In our setting, they reflect the fact that the user value of the intermediate goods or services produced by $\mathrm{j}$ that has increased due to a productivity gain from offshoring is not fully accounted for in their price. Hall et al. (2009) name several reasons why this may occur in the case of R\&D expenditure. In the case of offshoring, either firms are indeed not able to reap the full benefits of their offshoring decisions due to imperfect information, transaction costs or changes in the structure of the market for their output, or the true value of the transaction is not measured accurately in the available data. In the first case, the competitiveness of the market plays a crucial

11 Note that Daveri and Jona-Lasino (2008) and Winkler (2010) only estimate TFP growth based on value-added per worker. 
role, whereas the second case hinges upon the quality of the data and the possibility of measuring the real user value of inputs.

The second type of spillovers identified in Griliches (1992) are the so-called 'pure knowledge spillovers' from R\&D expenditure. They originate from the non-rival knowledge produced through research done by industry $j$, which turns out to be useful for industry i. Although such spillovers cannot be completely ruled out in the case of offshoring, we believe them to be a lot less likely to occur given that offshoring is generally aimed at reducing costs rather than creating productivity-enhancing knowledge. Without knowledge creation there is indeed no scope for knowledge spillovers. Therefore, our focus is on rent spillovers. ${ }^{12}$

A good example of rent spillovers from offshoring is given by business services offshoring. Firms that offshore business services such as accounting or call centres are believed to become more efficient through the reallocation of resources to their more productive core-business thereby raising the user-value of their output. However, it is not certain that these efficiency gains are entirely reflected in the price or value of their output that is purchased by other firms. Hence, extending to all types of intermediate purchases, there is a case for taking offshoring in the production of good or service $j$ into account in the estimation of TFP growth for industry $i$ in the proportion of i's purchases of good or service $j$ from domestic producers. For industry $i$ in year $\mathrm{t}$, the spillover terms for materials and business services offshoring s_om and s_os can be written as follows:

$$
\begin{aligned}
& s_{-} o m_{i t}=\sum_{j=1}^{J} w_{i j t} o m_{j t}^{p} \\
& s_{-} o s_{i t}=\sum_{j=1}^{J} w_{i j t} o s_{j t}^{p}
\end{aligned}
$$

where $\mathrm{w}_{\mathrm{ijt}}$ corresponds to the weight for purchases of input $\mathrm{j}$ by industry $\mathrm{i}$. The terms omj $\mathrm{p}^{\mathrm{p}}$ and os $^{\mathrm{p}}$ are the materials and business services offshoring intensities for the production of intermediate good or service j. As we work with data from SUT rather than product by product IOT, we cannot simply take the offshoring intensities for industry $j\left(\mathrm{om}_{\mathrm{j}}\right.$ and $\mathrm{os}$ ) to represent the offshoring intensities for the production of product j. SUT are based on heterogeneous industries, which implies that industries have secondary output of products other than their main product, i.e. product $j$ is not necessarily produced only by industry $j$. Hence, we proxy the (materials or business services) offshoring intensity in the production of product $j\left(\mathrm{om}_{\mathrm{j}} \mathrm{p}\right.$ and $\mathrm{osj}_{\mathrm{j}} \mathrm{p}$ ) as a weighted average of the (materials or business services) offshoring intensities in all industries that produce $j$ where the weights are the shares of the industries in the total output of $j$. These weights are computed from the supply table.

12 Next to the above-mentioned literature on spillovers from R\&D expenditure, there is also a vast literature on spillovers from foreign direct investment (FDI), which is reviewed in Görg and Greenaway (2004). Although the focus is mainly on knowledge spillovers within industries, some papers specifically look at spillovers between industries. The latter comes closest to our treatment of productivity spillovers from offshoring. 


$$
\begin{aligned}
& o m_{j t}^{p}=\sum_{i=1}^{I} \frac{Y_{i j t}}{Y_{j t}} o m_{i t} \\
& o s_{j t}^{p}=\sum_{i=1}^{I} \frac{Y_{i j t}}{Y_{j t}} o s_{i t}
\end{aligned}
$$

where $Y_{i}$ is output of product $j$ by industry $i$ and $Y_{j}$ is the total output of product $j$, i.e. $Y_{j}=\sum_{i} Y_{i j}$.

The spillover-term formulation with weights $w_{\mathrm{ijt}}$ in (3) and (4) mirrors the one developed in Griliches (1979) for R\&D expenditure. The exact formulation of the weights to be used in the R\&D-spillover terms is the subject of a long-standing debate as documented in van Pottelsberghe de la Potterie (1997) and Hall et al. (2009). In the presence of knowledge spillovers the weights are supposed to measure the technological proximity of industries or firms. Several different technological proximity weights, e.g. based on patents or citations, have been tested in the literature. However, for measuring rent spillovers, weights derived from economic transaction matrices are the most appropriate. Hence, following van Pottelsberghe de la Potterie (1997), we have chosen the following specification for the weights:

$w_{i j t}=\frac{I_{i j t}^{d}}{I_{i t}^{n e}}$

where the numerator $\left(\mathrm{Id}_{\mathrm{ijt}}\right)$ is purchases of product $\mathrm{j}$ by industry $\mathrm{i}$ from domestic producers of $\mathrm{j}$, and the denominator $\left(\mathrm{I}^{n} \mathrm{e}_{\mathrm{it}}\right)$ is total non-energy intermediates used by industry $\mathrm{i}^{13}$ Replacing $\mathrm{W}_{\mathrm{ijt}}$ in (3) and (4) by this expression allows to compute the offshoring spillover terms from SUT.

Finally, including the materials and business services offshoring spillover terms as extra technology shifters in the production function makes it possible to rewrite the estimating equation. However, the productivity spillovers from offshoring are unlikely to occur immediately as the productivity gains from offshoring have to materialise in the supplier industry first. There is thus a clear case for lagging the offshoring spillover terms and hence, (2) becomes:

$$
\begin{aligned}
d \ln Y_{i t}= & \alpha+\beta_{k} d \ln K_{i t}+\beta_{l} d \ln L_{i t}+\beta_{e} d \ln E_{i t}+\beta_{m} d \ln M_{i t}+\beta_{s} d \ln S_{i t} \\
& +\beta_{o m} d o m_{i t}+\beta_{o s} d o s_{i t}+\beta_{\text {som }} d s_{-} o m_{i t-1}+\beta_{\text {sos }} d s_{-} o s_{i t-1}+\gamma_{i} D_{i}+\gamma_{t} D_{t}+\varepsilon_{i t}
\end{aligned}
$$

If there are rent spillovers from offshoring, then $\beta_{\text {som }}$ and $\beta_{\text {sos }}$ should be positive.

We have taken equations (2) and (5) to the data. The results of the estimations are reported in the next section.

13 We would like to thank Bernadette Biatour for pointing out that there are other feasible denominators for these weights. Hence, we have computed alternative spillover terms with the following denominators in the weights (instead of $\left.Y_{i t}\right)$ : total output by industry $\left(Y_{i t}\right)$ and total output by product $\left(Y_{j t}\right)$. Estimating equation (5) with these alternative spillover terms does not change the results reported in the next section in terms of the significance of the spillover terms. These results are available upon request from the authors. 


\section{Results}

In this section, the results of estimating equations (2) and (5) are reported. Given that in the econometric approach to TFP growth estimation the $\beta$-parameters that define the production technology are constrained to take the same value for all industries in the sample, we have preferred to split the sample into manufacturing and market services so as to allow for differences in production technology between the two. A description of the sources for the data used in the estimations can be found in Appendix Table A2. Summary statistics for the variables that have not been discussed up to here are shown in Appendix Table A3. The data allow two further splits of variables. On the one hand, the labour variable is split by skill, which is proxied through educational attainment. We distinguish three skill levels: high-skilled (L_h), mediumskilled ( $\left.\mathrm{L} \_\mathrm{m}\right)$ and low-skilled $\left(\mathrm{L} \_\mathrm{l}\right) .{ }^{14}$ This distinction is made in all the regressions. On the other hand, the materials and business services offshoring intensities are split by region as explained in section 3. Estimations are then made separately for offshoring to OECD countries, to CEE countries and to Asian countries. ${ }^{15}$ We have furthermore computed spillover terms for the regional offshoring intensities. They are also marked by the suffix of the respective region (_oecd, _ceec, _asia). The results of the estimations with the overall materials and business services offshoring intensities om and os are reported in Tables 1 and 2 below, while those of the estimations with the regional offshoring intensities can be found in Tables 3 and 4 .

Running a standard ordinary least squares (ols) regression of equation (2) yields the results shown in column (1) of Tables 1 and 2 for manufacturing and market service industries. In the manufacturing industries, $\beta_{\mathrm{om}}$ is positive significant at the $1 \%$-level, i.e. materials offshoring leads to statistically significant productivity gains. But the impact is actually very small: ceteris paribus, the semi-elasticity of 0.3 implies that the 0.4 percentage point increase in om over 19952004 has produced a $0.12 \%$ rise in output. This must be compared to the $24.2 \%$ growth in total manufacturing output over the same period. The coefficient for business services offshoring $\left(\beta_{\circ s}\right)$ is not different from zero at any of the standard significance levels. This pattern is inverted in the market service industries: there is no productivity impact of materials offshoring and a positive significant impact of business services offshoring. Holding all other inputs constant, the value of 1.013 for $\beta_{\text {os }}$ means that the 2.3 percentage point increase in overall business services offshoring between 1995 and 2004 has raised output in market service industries by $2.3 \%$. Total output growth in those industries over the same period was $35.5 \%$. These results are not significantly altered by the inclusion of lags of the offshoring variables as shown in column (2) of Tables 1 and 2, while the coefficients of the lagged offshoring intensities are not significant.

14 In terms of the International Standard Classification of Education the split by skill is as follows: ISCED 1-2 (lowskilled), ISCED 3-4 (medium-skilled), ISCED 5-6 (high-skilled).

15 These regional splits are introduced in separate estimations to avoid multicollinearity problems. 
Table 1 Estimation results with total offshoring intensities (om and os) in manufacturing

\begin{tabular}{|c|c|c|c|c|c|}
\hline & (1) & (2) & (3) & $(4)$ & (5) \\
\hline & ols & ols & ols & gmm & gmm \\
\hline \multirow[t]{2}{*}{ Capital } & $0.125^{\star \star}$ & $0.124^{\star \star}$ & $0.119^{*}$ & $0.081^{*}$ & $0.131^{\star \star *}$ \\
\hline & $(0.050)$ & $(0.061)$ & $(0.067)$ & $(0.042)$ & $(0.047)$ \\
\hline \multirow[t]{2}{*}{ High-skilled labour } & $0.034^{\star *}$ & 0.030 & 0.031 & $0.075^{*}$ & 0.035 \\
\hline & $(0.016)$ & $(0.020)$ & $(0.020)$ & $(0.043)$ & $(0.038)$ \\
\hline \multirow[t]{2}{*}{ Medium-skilled labour } & 0.038 & $0.068^{\star \star}$ & $0.065^{\star \star}$ & 0.013 & 0.032 \\
\hline & $(0.031)$ & $(0.029)$ & $(0.030)$ & $(0.069)$ & $(0.066)$ \\
\hline \multirow[t]{2}{*}{ Low-skilled labour } & 0.012 & 0.012 & 0.008 & 0.113 & 0.011 \\
\hline & $(0.046)$ & $(0.051)$ & $(0.050)$ & $(0.093)$ & $(0.063)$ \\
\hline \multirow[t]{2}{*}{ Energy } & $0.056^{\star \star \star}$ & $0.057^{\star \star \star}$ & $0.055^{\star \star \star}$ & $0.059^{\star \star}$ & 0.029 \\
\hline & $(0.017)$ & $(0.017)$ & $(0.016)$ & $(0.022)$ & (0.039) \\
\hline \multirow[t]{2}{*}{ Materials } & $0.443^{\star \star \star}$ & $0.437^{\star \star \star}$ & $0.438^{\star \star \star}$ & 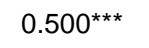 & $0.548^{\star \star \star}$ \\
\hline & $(0.039)$ & $(0.044)$ & $(0.042)$ & $(0.050)$ & $(0.059)$ \\
\hline \multirow[t]{2}{*}{ Services } & $0.240^{\star \star \star}$ & $0.250^{\star \star \star}$ & 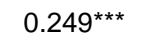 & $0.178^{\star \star \star}$ & $0.229^{\star \star \star}$ \\
\hline & $(0.032)$ & $(0.035)$ & $(0.034)$ & $(0.033)$ & $(0.033)$ \\
\hline \multirow[t]{2}{*}{ Materials offshoring } & $0.300^{\star \star *}$ & $0.293^{\star \star \star}$ & $0.335^{\star \star \star}$ & -0.275 & -0.145 \\
\hline & $(0.086)$ & $(0.094)$ & $(0.093)$ & $(0.281)$ & $(0.245)$ \\
\hline \multirow[t]{2}{*}{ Services offshoring } & 1.316 & 1.624 & 1.425 & $5.437^{\star \star}$ & $4.353^{*}$ \\
\hline & $(1.443)$ & $(1.513)$ & $(1.594)$ & $(2.114)$ & $(2.517)$ \\
\hline \multirow[t]{2}{*}{ Materials offshoring, t-1 } & & -0.148 & & & \\
\hline & & $(0.093)$ & & & \\
\hline \multirow[t]{2}{*}{ Services offshoring, t-1 } & & -0.513 & & & \\
\hline & & $(0.889)$ & & & \\
\hline \multirow[t]{2}{*}{ Materials offshoringspillovers, $\mathrm{t}-1$} & & & -0.014 & & $0.498^{*}$ \\
\hline & & & $(0.084)$ & & $(0.275)$ \\
\hline \multirow[t]{2}{*}{ Services offshoring spillovers, $\mathrm{t}-1$} & & & -1.612 & & 0.329 \\
\hline & & & $(1.106)$ & & $(2.285)$ \\
\hline $\mathrm{N}$ & 567 & 504 & 504 & 630 & 567 \\
\hline R-sq & 0.91 & 0.91 & 0.91 & & \\
\hline Autocorrelation (1st order) & & & & {$[0.031]$} & [0.079] \\
\hline Autocorrelation (2nd order) & & & & {$[0.275]$} & [0.420] \\
\hline Hansen J stat & & & & [0.655] & [0.693] \\
\hline
\end{tabular}

Source: own calculations

Remarks: 63 manufacturing industries covered; all equations include time and industry dummies; all variables are in natural logs (lower-case letters) except for the offshoring variables; robust standard errors reported in parentheses; ols: ordinary least squares estimations in differences for output; gmm: two step system generalised method of moments estimations for output; $\mathrm{N}$ : number of observations; R-sq: R-squared; ArellanoBond tests for 1st and 2nd order autocorrelation of the 1st differenced residuals in the gmm-estimations (p-values reported, HO: no autocorrelation); Hansen $\mathrm{J}$ stat: test of validity of over-identifying restrictions in the gmm-estimations ( $p$-values reported, H0: over-identifying restrictions valid); ${ }^{*} p<0.1,{ }^{*} p<0.05$, *** $p<0.01$. 
Table 2 Estimation results with total offshoring intensities (om and os) in market services

\begin{tabular}{|c|c|c|c|c|c|}
\hline & (1) & $(2)$ & (3) & $(4)$ & $(5)$ \\
\hline & ols & ols & ols & gmm & gmm \\
\hline \multirow[t]{2}{*}{ Capital } & -0.025 & 0.011 & 0.010 & 0.104 & 0.089 \\
\hline & $(0.086)$ & $(0.104)$ & $(0.104)$ & $(0.090)$ & $(0.088)$ \\
\hline \multirow[t]{2}{*}{ High-skilled labour } & 0.047 & 0.044 & 0.048 & 0.124 & 0.082 \\
\hline & $(0.042)$ & $(0.047)$ & $(0.048)$ & $(0.076)$ & $(0.078)$ \\
\hline \multirow[t]{2}{*}{ Medium-skilled labour } & 0.049 & 0.053 & 0.051 & 0.006 & -0.004 \\
\hline & $(0.034)$ & $(0.037)$ & $(0.038)$ & $(0.081)$ & $(0.130)$ \\
\hline \multirow[t]{2}{*}{ Low-skilled labour } & $0.067^{\star \star}$ & $0.062^{*}$ & $0.058^{*}$ & $0.129^{*}$ & 0.151 \\
\hline & $(0.030)$ & $(0.032)$ & $(0.030)$ & $(0.067)$ & $(0.148)$ \\
\hline \multirow[t]{2}{*}{ Energy } & $0.046^{\star \star *}$ & $0.046^{\star \star *}$ & $0.048^{\star \star \star}$ & 0.004 & -0.046 \\
\hline & $(0.010)$ & $(0.010)$ & $(0.010)$ & $(0.033)$ & $(0.108)$ \\
\hline \multirow[t]{2}{*}{ Materials } & $0.064^{\star \star \star}$ & $0.058^{\star \star \star}$ & $0.058^{\star \star \star}$ & $0.067^{\star \star}$ & $0.078^{\star}$ \\
\hline & $(0.011)$ & $(0.010)$ & $(0.011)$ & $(0.029)$ & $(0.039)$ \\
\hline \multirow[t]{2}{*}{ Services } & $0.436^{\star * *}$ & $0.446^{\star \star *}$ & $0.446^{\star \star \star}$ & $0.559^{\star \star \star}$ & $0.674^{\star \star \star}$ \\
\hline & $(0.033)$ & $(0.037)$ & $(0.035)$ & $(0.135)$ & $(0.170)$ \\
\hline \multirow[t]{2}{*}{ Materials offshoring } & -0.106 & -0.194 & -0.202 & -0.617 & -1.514 \\
\hline & $(0.242)$ & $(0.253)$ & $(0.264)$ & $(1.289)$ & $(2.309)$ \\
\hline \multirow[t]{2}{*}{ Services offshoring } & $1.013^{\star \star \star}$ & $0.966^{\star \star}$ & $0.887^{\star \star}$ & 1.852 & 1.240 \\
\hline & $(0.314)$ & $(0.415)$ & $(0.376)$ & $(1.752)$ & $(2.041)$ \\
\hline \multirow[t]{2}{*}{ Materials offshoring, $\mathrm{t}-1$} & & 0.091 & & & \\
\hline & & $(0.196)$ & & & \\
\hline \multirow[t]{2}{*}{ Services offshoring, t-1 } & & 0.570 & & & \\
\hline & & $(0.398)$ & & & \\
\hline \multirow[t]{2}{*}{ Materials offshoringspillovers, $\mathrm{t}-1$} & & & -0.205 & & 1.616 \\
\hline & & & $(0.217)$ & & $(2.094)$ \\
\hline \multirow[t]{2}{*}{ Services offshoring spillovers, t-1 } & & & -0.636 & & 1.335 \\
\hline & & & $(0.696)$ & & $(3.798)$ \\
\hline $\mathrm{N}$ & 360 & 320 & 320 & 400 & 360 \\
\hline R-sq & 0.84 & 0.84 & 0.84 & & \\
\hline Autocorrelation (1st order) & & & & [0.093] & {$[0.156]$} \\
\hline Autocorrelation (2nd order) & & & & {$[0.820]$} & {$[0.227]$} \\
\hline Hansen J stat & & & & {$[0.501]$} & {$[0.673]$} \\
\hline
\end{tabular}

Source: own calculations

Remarks: 40 market services industries covered; all equations include time and industry dummies; all variables are in natural logs except for the offshoring variables; robust standard errors reported in parentheses; ols: ordinary least squares estimations in differences for output; gmm: two step system generalised method of moments estimations for output; N: number of observations; R-sq: R-squared; Arellano-Bond tests for 1st and 2nd order autocorrelation of the 1st differenced residuals in the gmm-estimations ( $p$-values reported, HO: no autocorrelation); Hansen $\mathrm{J}$ stat: test of validity of over-identifying restrictions in the gmm-estimations ( $p$-values reported, H0: over-identifying restrictions valid); ${ }^{*}<0.1,{ }^{\star \star} p<0.05$, ${ }^{\star \star *} p<0.01$.

In line with the discussion of the estimation strategy in Section 4, we have tried to tackle the potential endogeneity bias of the variable inputs energy, materials and services, and of the offshoring intensities in different ways. First, the regressions of columns (1) and (2) contain industry dummies to capture any time-invariant industry-specific endogeneity between offshoring and productivity. Second, we have run regressions with value-added per hour worked as dependent variable, thereby excluding the above-mentioned variable inputs as regressors and avoiding the endogeneity problem for those variable inputs (Appendix Tables A4 and A5). Ma- 
terials offshoring remains positive significant in manufacturing industries and so does business services offshoring in market service industries. Moreover, business services offshoring now also leads to significant productivity gains in manufacturing. This is in line with the trends shown on Graphs A1-A8 in the appendix.

However, this does not address the problem of the potential endogeneity of the offshoring variables. Therefore, we have estimated equation (2) in levels with the GMM-SYS method taking the variable inputs and the offshoring intensities to be endogenous. ${ }^{16}$ The results are reported in column (4) of Tables 1 and 2. This is our preferred specification precisely because it tackles the problem of the endogeneity of offshoring. Neither materials offshoring in manufacturing nor business services offshoring in market services is significant. Only business services offshoring is found to have a significant productivity-enhancing effect in manufacturing. This result is confirmed by the estimations with the regional offshoring intensities, which are summed up in the columns with label (4) in Tables 3 and $4 .{ }^{17}$ The productivity gains through the business services offshoring intensity in manufacturing are essentially due to offshoring to OECD countries. ${ }^{18}$

Table 3 GMM-SYS estimation results with regional offshoring intensities in manufacturing

(4)

(5)

\begin{tabular}{|c|c|c|c|c|c|c|}
\hline & OECD & CEEC & ASIA & OECD & CEEC & ASIA \\
\hline Materials offshoring & -0.354 & -1.717 & -0.411 & -0.180 & -1.587 & -1.664 \\
\hline Services offshoring & $5.949 * \star$ & 101.013 & 83.364 & $4.878^{*}$ & 46.225 & 115.612 \\
\hline Materials offshoring spillovers & & & & 0.519 & 10.181 & 6.863 \\
\hline Services offshoring spillovers & & & & 0.035 & 103.063 & 169.294 \\
\hline $\mathrm{N}$ & 630 & 630 & 630 & 567 & 567 & 567 \\
\hline Autocorrelation ( $1^{\text {st }}$ order) & {$[0.037]$} & {$[0.017]$} & {$[0.015]$} & [0.081] & {$[0.037]$} & {$[0.016]$} \\
\hline Autocorrelation ( $2^{\text {nd }}$ order $)$ & [0.325] & [0.596] & {$[0.316]$} & [0.429] & {$[0.626]$} & [0.403] \\
\hline Hansen J stat & {$[0.671]$} & {$[0.315]$} & [0.883] & {$[0.767]$} & [0.632] & {$[0.232]$} \\
\hline
\end{tabular}

Source: own calculations

Remarks: 63 manufacturing industries covered; two step system generalised method of moments estimations for output; identical to specifications (4) and (5) in Tables 1 and 2; results for input variables (capital, high-skilled labour, medium-skilled labour, low-skilled labour, energy, materials and services) not shown but available from the authors upon request; N: number of observations; Arellano-Bond tests for 1st and 2nd order autocorrelation of the 1st differenced residuals in the gmm-estimations ( $p$-values reported, HO: no autocorrelation); Hansen $\mathrm{J}$ stat: test of validity of over-identifying restrictions in the gmm-estimations ( $p$-values reported, H0: overidentifying restrictions valid); ${ }^{*} p<0.1,{ }^{* *} p<0.05,{ }^{* *} p<0.01$.

16 We have nonetheless limited the number of lags of the endogenous variables in levels that are used in the estimation of the differenced equation to two for the variable inputs and to three for the offshoring intensities.

17 The results for the control variables are omitted in Tables 3 and 4 . They do not change in any significant way compared to the estimations with the total offshoring intensities. We can provide those results upon request.

18 As shown in Table 4, service offshoring to Asian countries has a significant positive impact on TFP in market services. However, since the percentage point increase in service offshoring to Asian countries is only approximately 0.0002 over $1995-2004$, the resulting output growth is less than $0.02 \%$ and hence not economically significant. 


\begin{tabular}{|c|c|c|c|c|c|c|}
\hline & \multicolumn{3}{|c|}{ (4) } & \multicolumn{3}{|c|}{$(5)$} \\
\hline & OECD & CEEC & ASIA & OECD & CEEC & ASIA \\
\hline Materials offshoring & -0.617 & -6.723 & 0.134 & -1.109 & 2.724 & -1.314 \\
\hline Services offshoring & 2.206 & -47.576 & $65.085^{\star}$ & 0.848 & -61.451 & 60.485 \\
\hline Materials offshoring spillovers & & & & 1.211 & -52.008 & 5.895 \\
\hline Services offshoring spillovers & & & & 1.252 & -2.915 & -29.065 \\
\hline $\mathrm{N}$ & 400 & 400 & 400 & 360 & 360 & 360 \\
\hline Autocorrelation ( $1^{\text {st }}$ order $)$ & [0.096] & {$[0.010]$} & [0.059] & {$[0.258]$} & {$[0.939]$} & {$[0.074]$} \\
\hline Autocorrelation ( $2^{\text {nd }}$ order) & {$[0.838]$} & {$[0.461]$} & {$[0.454]$} & {$[0.339]$} & {$[0.806]$} & {$[0.729]$} \\
\hline Hansen $\mathrm{J}$ stat & [0.463] & {$[0.750]$} & {$[0.176]$} & {$[0.654]$} & [0.916] & [0.632] \\
\hline
\end{tabular}

Source: own calculations

Remarks: 40 market services industries covered; two step system generalised method of moments estimations for output; identical to specifications (4) and (5) in Tables 1 and 2; results for input variables (capital, high-skilled labour, medium-skilled labour, low-skilled labour, energy, materials and services) not shown but available from the authors upon request; N: number of observations; Arellano-Bond tests for 1st and 2nd order autocorrelation of the 1st differenced residuals in the gmm-estimations ( $p$-values reported, HO: no autocorrelation); Hansen $\mathrm{J}$ stat: test of validity of over-identifying restrictions in the gmm-estimations ( $p$-values reported, HO: overidentifying restrictions valid); ${ }^{*} p<0.1,{ }^{* *} p<0.05,{ }^{* * *} p<0.01$

To complete the set of estimations, the lagged offshoring spillover terms are included in the equations. The results of running a standard ols regression of equation (5) can be found in columns (3) of Tables 1 and 2. They suggest that offshoring does not produce any spillover effects on productivity as none of the spillover terms is significantly different from zero. In other words, there are no rent spillovers from either materials or business services offshoring in domestic supplier industries. However, this result changes slightly when estimating equation (5) in levels by GMM-SYS (column (5) in Tables 1 and 2). In this specification - our preferred one there is some evidence of positive spillovers from materials offshoring in manufacturing. But the coefficient proves to be only weakly significant and this spillover effect is not confirmed by the estimations with the regional offshoring intensities (columns with label (5) in Table 3). The GMM-SYS estimations for market services produce no evidence of spillovers from offshoring. As a further robustness test, we have included two-period and three-period lags of the spillover terms in equation (5) without finding any significant result for the spillover terms. Finally, we have also tested for state dependency in specifications (4) and (5) for both manufacturing and market services by introducing the lagged dependent variable as a regressor and applying GMM-SYS for estimation. The results do not change substantially with respect to those shown in Tables 1 and 2 and the lagged dependent variables turn out to be non-significant. ${ }^{19}$

To sum things up, according to our preferred specification materials offshoring does not lead to productivity gains over the years 1995 to 2004 in either manufacturing or market services. This does not really come as a surprise. Materials offshoring in manufacturing already stood at high levels at the beginning of the period and its growth is rather weak. It looks like it is mature and has produced its productivity enhancing effect during its growth period before 1995. This rea-

19 For the sake of brevity, the results for these robustness tests (extra lags of the spillover terms and state dependency) are not shown but can be obtained from the authors upon request. 
soning is consistent with the fact that materials offshoring has been going on for a long time in Belgian manufacturing industries, i.e. it has already occurred many years before the start of our sample. Things are different for business services offshoring, which, according to our results, does play a productivity-enhancing role. In our preferred specification, there is evidence of a positive statistically and economically significant impact of business services offshoring on productivity in manufacturing. The regional splits of the offshoring intensities show that this result is driven by offshoring to OECD countries. Business services offshoring starts from low levels in 1995 - especially in manufacturing - but grows fast. Firms are only beginning to make use of the relatively new possibility of business services offshoring, which has come about through an increase in the tradability of those services fostered by liberalisation and technological developments. Productivity gains are beginning to show, but it is likely that they have not entirely materialised yet.

Linking these results to the findings in Michel and Rycx (2011), we can provide a richer story with two separate explanations for why offshoring has no impact on industry-level employment in Belgium. On the one hand, the slow growth of materials offshoring does not produce a significant impact on either employment or productivity. Fast growing business services offshoring, on the other hand, proves to be productivity-enhancing and, in terms of employment, direct losses through the shift abroad of such service activities are compensated for by gains through an expansion in output that is driven by the rise in productivity. In this context, another line of reasoning may be put forward. Given public pressure surrounding job losses through offshoring, firms may have adapted their offshoring strategy, seeking only productivity improvements, while deliberately limiting the impact on the size of their workforce.

Finally, the almost complete lack of evidence of productivity spillovers from offshoring also deserves some further discussion. As argued above, knowledge spillovers from offshoring seem a priori rather unlikely, hence our focus on rent spillovers. The admittedly rather weak evidence of productivity gains from materials offshoring in manufacturing could indicate that they accrue to user industries rather than to the offshoring industries. However, the absence of spillovers from offshoring in almost all cases suggests that firms manage to internalise the entire efficiency benefit from offshoring. This seems particularly plausible when offshoring represents a survival strategy where firms try to catch up with average prices on the market for their output. Another explanation for the absence of spillovers from offshoring in our results is that they accrue to final consumers. Indeed, in our setting spillovers are limited to intermediate demand. If most offshoring occurs in industries that mainly produce for final demand, e.g. the food industry, then the scope for spillovers in intermediate demand is reduced. Developing an estimation strategy for the gains from offshoring that accrue to final consumers is beyond the scope of this paper. 


\section{Conclusion}

The productivity-enhancing nature of offshoring is well established from the point of view of economic theory and constitutes an assumption that is implicitly made in most analyses of offshoring and its consequences. Indeed, improving the efficiency of production is part of firms' motivations when they engage in offshoring. Nevertheless, determining whether such productivity gains from offshoring do effectively materialise remains an empirical question. A growing body of literature attempts to answer this question.

This article presents industry-level evidence on the impact of materials and business services offshoring on productivity for Belgium over 1995-2004. Industry-level offshoring intensities are measured by the classical proxy based on imported intermediates that was pioneered by Feenstra and Hanson (1996). Here, they are computed in constant prices for materials and business services from a consistent time series of supply and use tables. Moreover, this is one of the first articles to investigate this issue separately for market service industries. Including the offshoring intensities as a technology shifter in TFP growth regressions, we find that materials offshoring has barely any impact on productivity growth in either manufacturing or market services, while business services offshoring entails significant productivity gains in manufacturing. This is due to business services offshoring being an expanding phenomenon, whereas materials offshoring is mature and stagnating. Given the observed trend, it seems likely that productivity gains from materials offshoring have not entirely materialised yet. Regional splits of the offshoring intensities allow us to show that the productivity gains from business services offshoring in manufacturing are driven by offshoring to high-wage OECD countries.

Furthermore, this article adds to the existing literature by extending the TFP growth framework to include the possibility of rent spillovers from offshoring. This reflects the idea that the productivity gains from offshoring in the production of a good or service may feed through to industries that purchase the good or service for intermediate use. There is scope for such rent spillovers when the user value of the good or service exceeds its price, i.e. when firms fail to reap the full gains from offshoring. Given the cost savings motivation that largely drives offshoring, we do not believe in the possibility of knowledge spillovers from offshoring. In the event of rent spillovers from offshoring, the social return from offshoring will be greater than the private return. However, in our data, the evidence of spillovers from offshoring is so scarce and weak that we conclude that firms do indeed manage to internalise all efficiency gains from offshoring. In other words, rent spillovers are effectively prevented. 


\section{References}

Amiti, M., and Wei, S. (2005), "Fear of service outsourcing: is it justified?", Economic Policy, April 2005, vol. 20 (42), pp.308-347

Amiti, M., and Wei, S. (2006), "Service outsourcing, productivity and employment: evidence from the US", CEPR Discussion Paper n5475, February 2006

Amiti, M., and Wei, S. (2009), "Service offshoring and productivity: evidence from the US", The World Economy, February 2009, vol. 32 (2), pp. 203-220

Arellano, M., and Bond, S. (1991), "Some Tests of Specification for Panel Data: Monte Carlo Evidence and an Application to Employment Equations", Review of Economic Studies 58 (2), pp.277-297

Avonds, L., Hambÿe, C. and Michel, B. (2007), "Supply and Use Tables for Belgium 1995-2002: Methodology of Compilation", Federal Planning Bureau, Working Paper 4-07, February 2007, Brussels

Bhagwati, J., Panagariya, A., and Srinivasan, T. (2004), “The Muddles over Outsourcing", Journal of Economic Perspectives 18 (4), pp.93-114

Biatour, B., Bryon, G., and Kegels, C. (2007), "Capital services and total factor productivity measurements : impact of various methodologies for Belgium", Federal Planning Bureau, Working Paper 3-07, March 2007, Brussels

Biatour, B., and Kegels, C. (2008), "Growth and Productivity in Belgium", Federal Planning Bureau, Working Paper 17-08, September 2008, Brussels

Blundell, R., and Bond, S. (1998), "Initial conditions and moment restrictions in dynamic panel data models", Journal of Econometrics 87 (1), pp.115-143

Bresseleers, V., Hendrickx, K., Hertveldt, B., Van den Cruyce, B., and Wera, J. (2007), “Kwalitatieve werkgelegenheidsdata voor België, een SAM-aanpak voor de periode 1999-2005", Federal Planning Bureau, Working Paper 2-07, February 2007, Brussels

Cheung, C., Rossiter, J., and Zheng, Y. (2008), “Offshoring and Its Effects on the Labour Market and Productivity: A Survey of Recent Literature", Bank of Canada Review, Autumn 2008, pp.15-28

Coucke, K., and Sleuwaegen, L. (2008), “Offshoring as a survival strategy: evidence from manufacturing firms in Belgium", Journal of International Business Studies 39 (8), pp.1261-1277

Crino, R. (2008), "Service offshoring and productivity in Western Europe", Economics Bulletin, Vol. 6 (35), pp.1-8

Crino, R. (2009), "Offshoring, multinationals and the labour market: a review of the empirical literature", Journal of Economic Surveys, vol. 23 (2), pp.197-249 
Criscuolo, C., and Leaver, M. (2005), "Offshore Outsourcing and Productivity", unpublished, OECD

Daveri, F. and Jona-Lasino, C. (2008), "Off-shoring and Productivity Growth in the Italian Manufacturing Industries", CESIfo Working Paper N²288, April 2008

Deardorff, A. (2006), “Comment on Mankiw and Swagel, 'The politics and economics of offshore outsourcing'", Journal of Monetary Economics 53, pp.1057-1061

Egger, H., and Egger, P. (2006), "International Outsourcing and the Productivity of Low-skilled Labour in the EU", Economic Inquiry 44(1), p.98-108

Egger, P., Pfaffermayr, M., and Wolfmayr-Schnitzer, Y. (2001), “The international fragmentation of Austrian manufacturing: The effects of outsourcing on productivity and wages", North American Journal of Economics and Finance 12, pp. 257-272

Feenstra, R. and Hanson, G. (1996), "Globalisation, Outsourcing, and Wage Inequality", American Economic Review, vol. 86 (2), pp.240-245

Feenstra, R. and Hanson, G. (1999), “The Impact of Outsourcing and High-Technology Capital on Wages: Estimates for the United States, 1979-1990", The Quarterly Journal of Economics, vol. 114 (3), pp.907-940

Görg, H. and Greenaway, D. (2004), Much Ado about Nothing? Do Domestic Firms Really Benefit from Foreign Direct Investment?, The World Bank Research Observer, vol. 19 (2), pp.171-197

Görg, H., and Hanley, A. (2005), "International outsourcing and productivity: evidence from the Irish electronics industry", North American Journal of Economics and Finance 16, pp.255269

Görg, H., Hanley, A., and Strobl, E. (2008), "Productivity effects of international outsourcing: evidence from plant level data", Canadian Journal of Economics 41 (2), pp.670-688

Griliches, Z. (1979), "Issues in Assessing the Contribution of Research and Development to Productivity Growth", The Bell Journal of Economics, vol. 10 (1), pp. 92-116

Griliches, Z. (1992), "The Search for R\&D Spillovers", Scandinavian Journal of Economics 94, pp. 29-47

Hall, B., Mairesse, J., and Mohnen, P. (2009), “Measuring the returns to R\&D”, NBER Working Paper n¹5622, December 2009

Hambÿe, C. (2001), "La matrice importée des services", unpublished, internal document, Federal Planning Bureau, Brussels

Hijzen, A. (2005), "A bird's eye view of international outsourcing: data, measurement and labour demand", Economie Internationale 104, pp.45-63

Hijzen, A., Inui, T., and Todo, Y. (2010), “Does offshoring pay? Firm-level evidence from Japan", Economic Enquiry, October 2010, Vol. 48 (4), pp.880-895 
Ito, K., and Tanaka, K. (2010), “Does Material and Service Offshoring Improve Domestic Productivity? Evidence from Japanese Manufacturing Industries", RIETI Discussion Paper 10-E010, February 2010

Kohler, W. (2004), "Aspects of International Fragmentation", Review of International Economics, 12 (5), pp.793-816

Michel, B. (2008), "Trade-based measures of offshoring: an overview for Belgium", Federal Planning Bureau, Working Paper 9-08, March 2008, Brussels

Michel, B. (2010), “Stock de capital par branche SUT 1995-2004", unpublished, internal document, Federal Planning Bureau, Brussels

Michel, B., and Rycx, F. (2011), "Does offshoring of materials and business services affect employment? Evidence for a small open economy", Applied Economics, forthcoming

Moser, C., Urban, D., and Weder di Mauro, B. (2009), "Offshoring, firm performance and plantlevel employment - identifying productivity and downsizing effects", CEPR Discussion Paper $n^{\circ} 7455$, September 2009

OECD (2001), "Measuring Productivity - OECD Manual - Measurement of Aggregate and Industry-level Productivity Growth", Paris.

OECD (2007a), “Offshoring and Employment: Trends and Impacts”, Paris.

OECD (2007b), "Staying Competitive in the Global Economy: Moving Up the Value Chain", Paris.

Olsen, K. (2006), "Productivity Impacts of Offshoring and Outsourcing: A Review", OECD Science, Technology and Industry Working Papers, 2006/1, Paris.

UNCTAD (2004), "The offshoring of corporate service functions: the next global shift?", Chapter IV of the World Investment Report 2004, United Nations, New York and Geneva

Samuelson, P. (2004), "Where Ricardo and Mill Rebut and Confirm Arguments of Mainstream Economists Supporting Globalization", Journal of Economic Perspectives 18 (3), pp.135-146

Van den Cruyce, B. (2004), “Use Tables for Imported Goods and Valuation Matrices for Trade Margins -- an Integrated Approach for the Compilation of the Belgian 1995 Input-Output Tables", Economic Systems Research, vol. 16 (1), pp.33-61

Van Pottelsberghe de la Potterie, B. (1997), "Issues in Assessing the Impact of Interindustry R\&D Spillovers", Economic Systems Research, vol. 9 (4), pp. 331-356

Winkler, D. (2010), "Services Offshoring and its Impact on Productivity and Employment: Evidence from Germany, 1995-2006", The World Economy, December 2010, vol. 33 (12), pp.1672-1701

WTO (2005), "Offshoring Services: Recent Developments and Prospects", Chapter C of the World Trade Report 2005, World Trade Organisation, Geneva 


\section{Appendix}

\section{Table A1 List of industries, sut-code and description}

14A Mining and quarrying of stone, sand, clay and chemical and fertilizer materials, production of salt, and other mining and quarrying n.e.c.

15A Production, processing and preserving of meat and meat products

15B Processing and preserving of fish and fish products

15C Processing and preserving of fruit and vegetables

15D Manufacture of vegetable and animal oils and fats

$15 \mathrm{E}$ Manufacture of dairy products

15F Manufacture of grain mill products, starches and starch products

15G Manufacture of prepared animal feeds

$15 \mathrm{H}$ Manufacture of bread, fresh pastry goods, rusks and biscuits

15I Manufacture of sugar, chocolate and sugar confectionery

15J Manufacture of noodles and similar farinaceous products, processing of tea, coffee and food products n.e.c.

15K Manufacture of beverages except mineral waters and soft drinks

$15 \mathrm{~L}$ Production of mineral waters and soft drinks

16A Manufacture of tobacco products

$17 \mathrm{~A}$ Preparation and spinning of textile fibres, weaving and finishing of textiles

17B Manufacture of made-up textile articles, except apparel, other textiles, and knitted and crocheted fabrics

18A Manufacture of wearing apparel; dressing and dyeing of fur

19A Tanning and dressing of leather; manufacture of luggage, handbags, saddlery, harness and footwear

20A Manufacture of wood and of products of wood and cork, except furniture; manufacture of articles of straw

21A Manufacture of pulp, paper and paper products

22A Publishing

22B Printing and service activities related to printing, reproduction of recorded media

23A Manufacture of coke, refined petroleum products and nuclear fuel

24A Manufacture of basic chemicals

24B Manufacture of pesticides and other agro-chemical products

24C Manufacture of paints, varnishes and similar coatings, printing ink and mastics

24D Manufacture of pharmaceuticals, medicinal chemicals and botanical products

24E Manufacture of soap and detergents, cleaning and polishing preparations, perfumes and toilet preparations

24F Manufacture of other chemical products

24G Manufacture of man-made fibres

25A Manufacture of rubber products

25B Manufacture of plastic products

26A Manufacture of glass and glass products

26B Manufacture of ceramic products

26C Manufacture of cement, lime and plaster

26D Manufacture of articles of concrete, plaster and cement; cutting, shaping and finishing of stone; manufacture of other non-metallic mineral products

27A Manufacture of basic iron and steel and of ferro-alloys and tubes

27B Other first processing of iron and steel; manufacture of non-ferrous metals; casting of metals

28A Manufacture of structural metal products, tanks, reservoirs, containers of metal, central heating radiators, boilers and steam generators; forging, pressing, stamping and roll forming of metal

28B Treatment and coating of metals; general mechanical engineering

28C Manufacture of cutlery, tools, general hardware and other fabricated metal products

29A Manufacture of machinery for the production and use of mechanical power, except aircraft and vehicle engines

29B Manufacture of other general purpose machinery

29C Manufacture of agricultural and forestry machinery and of machine tools

29D Manufacture of domestic appliances

30A Manufacture of office machinery and computers 
31A Manufacture of electric motors, generators and transformers, of electricity distribution and control apparatus, and of insulated wire and cable

31B Manufacture of accumulators, batteries, lamps, lighting equipment and electrical equipment

32A Manufacture of radio, television and communication equipment and apparatus

33A Manufacture of medical, precision and optical instruments, watches and clocks

34A Manufacture of motor vehicles

34B Manufacture of bodies (coachwork) for motor vehicles, of trailers and parts and accessories for motor vehicles

35A Building and repairing of ships and boats; manufacture of locomotives and rolling stock, and of aircraft

35B Manufacture of motorcycles and bicycles and other transport equipment n.e.c.

36A Manufacture of furniture

36B Manufacture of jewellery and related articles

36C Manufacture of musical instruments, sports goods, games and toys; miscellaneous manufacturing

37A Recycling

45A Site preparation

45B General construction of buildings and civil engineer works; erection of roof covering and frames

45C Construction of motorways, roads, airfields, sports facilities and water projects; other construction work

45D Building installation

45E Building completion; renting of construction or demolition equipment with operator

$50 \mathrm{~A}$ Sale, maintenance and repair of motor vehicles and motorcycles, parts and accessories

$50 B$ Retail sale of automotive fuel

51A Wholesale trade and commission trade, except of motor vehicles and motorcycles

52A Retail trade, except of motor vehicles and motorcycles; repair of personal and household goods

$55 \mathrm{~A}$ Hotels and other provision of short-stay accommodation

55B Restaurants, bars, canteens and catering

$60 \mathrm{~A}$ Transport via railways

60B Other scheduled passenger land transport; taxi operation; other land passenger transport

60C Freight transport by road; transport via pipelines

$61 \mathrm{~A}$ Sea and coastal water transport

$61 B$ Inland water transport

62A Air transport

63A Activities of travel agencies and tour operators; tourist assistance activities n.e.c.

63B Cargo handling and storage, other supporting transport activities; activities of other transport agencies

64A Post and courier activities

64B Telecommunications

65A Financial intermediation, except insurance and pension funding

66A Insurance and pension funding, except compulsory social security

67A Activities auxiliary to financial intermediation

$70 A$ Real estate activities

71A Renting of automobiles and other transport equipment

71B Renting of machinery and equipment and personal and household goods

72A Computer and related activities

73A Research and development

74A Legal activities, accounting activities; market research and public opinion polling

74B Business and management consultancy activities; management activities of holding companies

74C Architectural and engineering activities and related technical consultancy

74D Advertising

74E Labour recruitment and provision of personnel

74F Investigation and security activities; industrial cleaning; miscellaneous business activities n.e.c.

80A Education (market sector)

85A Human health activities

85B Veterinary activities

85C Social work activities

91A Activities of membership organisations

92A Motion picture and video activities; radio and television activities 
92B Other entertainment activities

92C News agency activities and other cultural activities

92D Sporting and other recreational activities

93A Other service activities n.e.c.

Table A2 Data sources

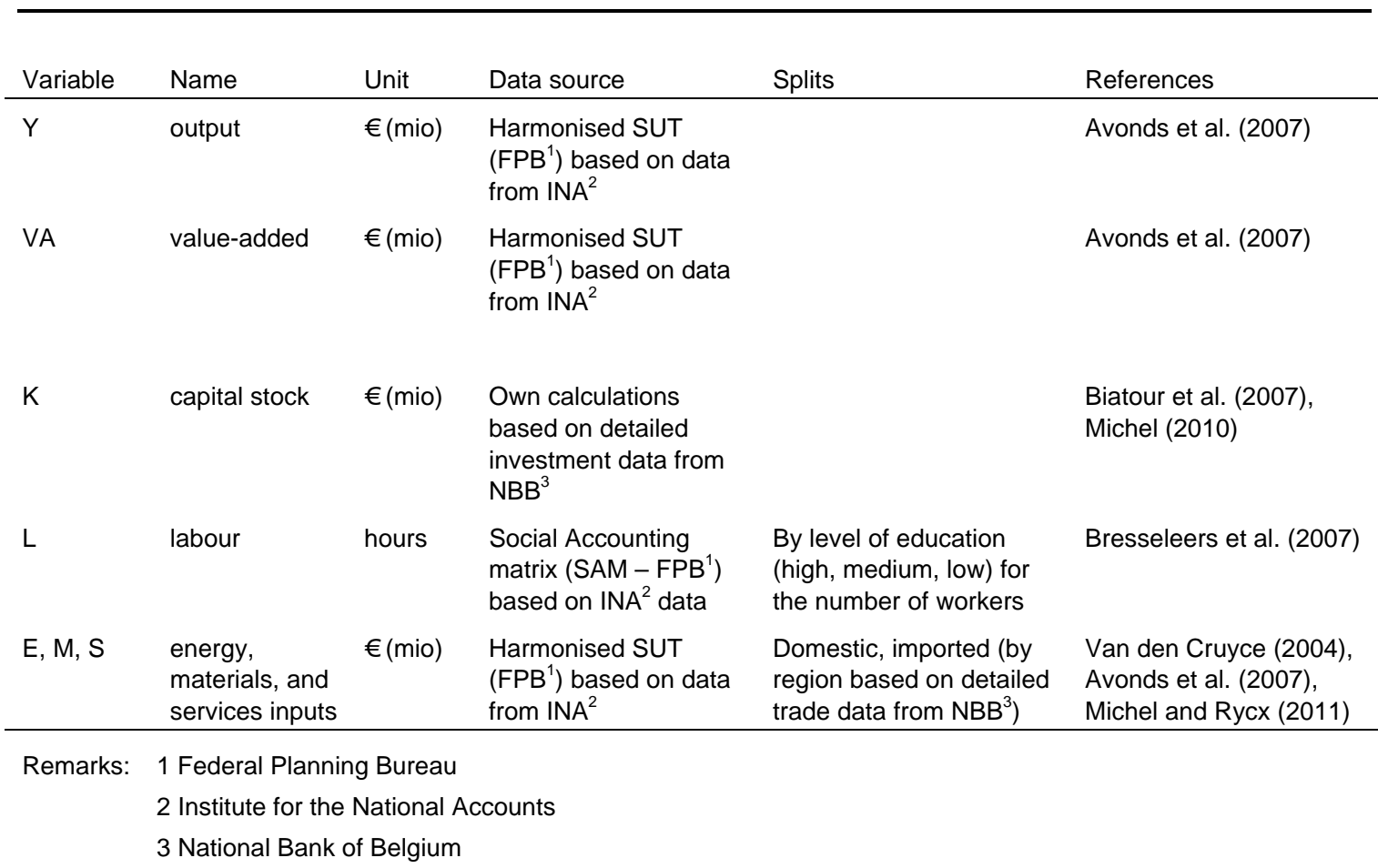

Table A3 Descriptive statistics

\begin{tabular}{lrrrr}
\hline & & & & \\
& 1995 & 2004 & abs change & avg g rate \\
\hline Manufacturing & & & & \\
Capital (millions of euros) & 89689 & 109583 & 19894 & $2.3 \%$ \\
High-skilled labour (millions of hours) & 208 & 244 & 36 & $1.8 \%$ \\
Medium-skilled labour (millions of hours) & 482 & 566 & 84 & $1.8 \%$ \\
Low-skilled labour (millions of hours) & 733 & 497 & -236 & $-4.2 \%$ \\
Energy (millions of euros) & 11710 & 17786 & 6076 & $4.8 \%$ \\
Materials (millions of euros) & 77440 & 89942 & 12501 & $1.7 \%$ \\
Services (millions of euros) & 37223 & 52239 & 15016 & $3.8 \%$ \\
Markets services & & & & \\
Capital (millions of euros) & 194769 & 241303 & 46535 & $2.4 \%$ \\
High-skilled labour (millions of hours) & 883 & 1209 & 326 & $3.6 \%$ \\
Medium-skilled labour (millions of hours) & 1007 & 1297 & 290 & $2.9 \%$ \\
Low-skilled labour (millions of hours) & 1014 & 890 & -124 & $-1.4 \%$ \\
Energy (millions of euros) & 6536 & 5400 & -1136 & $-2.1 \%$ \\
Materials (millions of euros) & 15479 & 24071 & 8592 & $5.0 \%$ \\
Services (millions of euros) & 73381 & 106504 & 33122 & $4.2 \%$ \\
\hline
\end{tabular}

Source: see Table A2; own calculations 
Graph A1 Year-on-year variations in value-added per hour worked (va/l - RHS) and regional and overall materials offshoring (om, om_oecd, om_ceec, om_asia, om_rest - LHS) in manufacturing

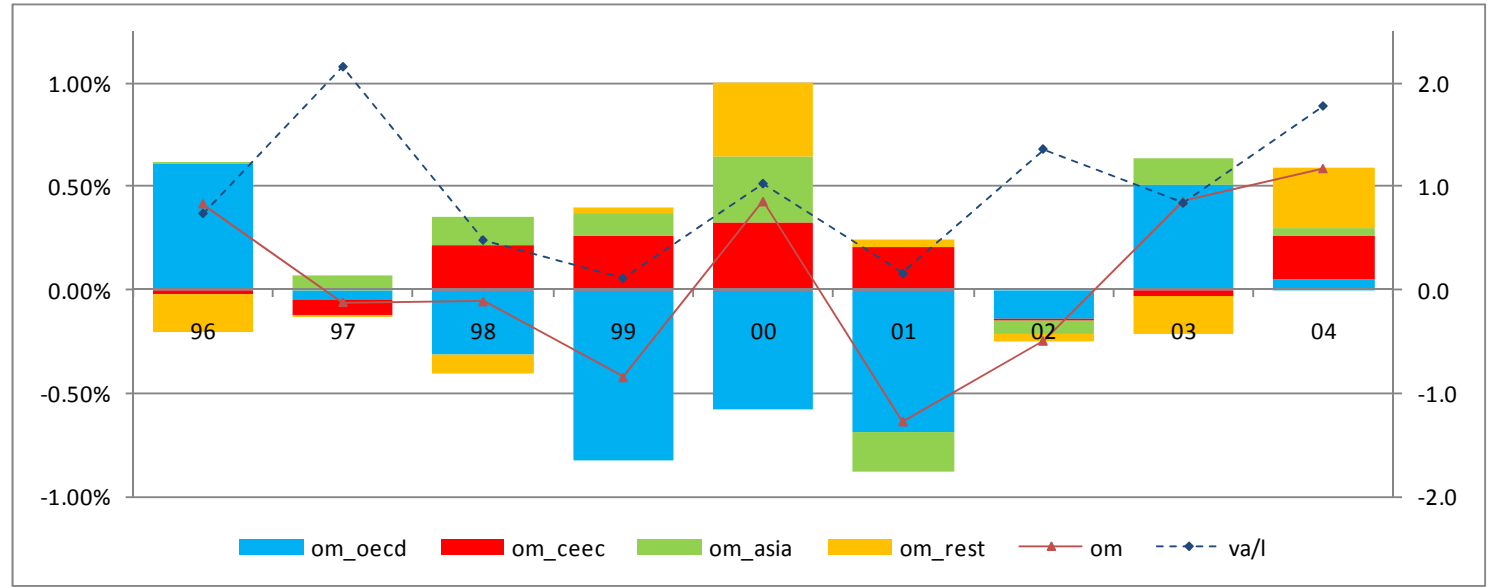

Source: own calculations

Graph A2 Year-on-year variations in value-added per hour worked (va/l - RHS) and regional and overall business services offshoring (os, os_oecd, os_ceec, os_asia, os_rest - LHS) in manufacturing

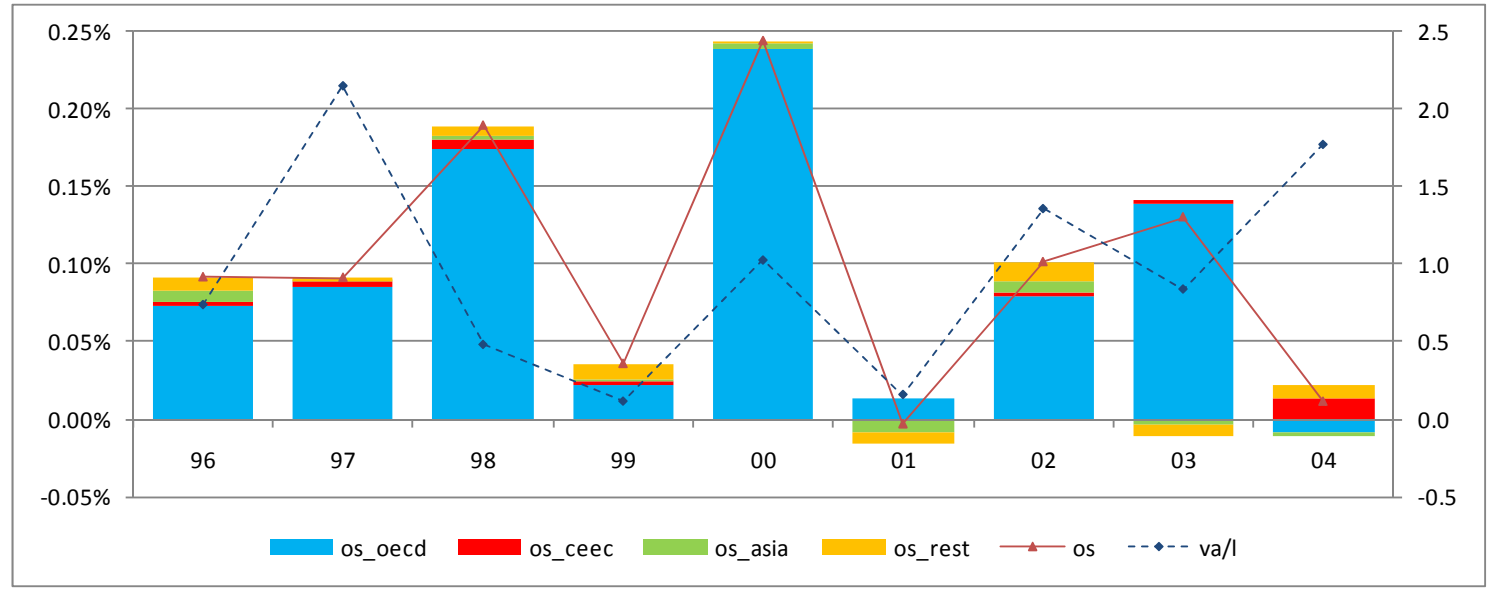

Source: own calculations 
Graph A3 Year-on-year variations in value-added per hour worked (va/l - RHS) and regional and overall materials offshoring (om, om_oecd, om_ceec, om_asia, om_rest - LHS) in market services

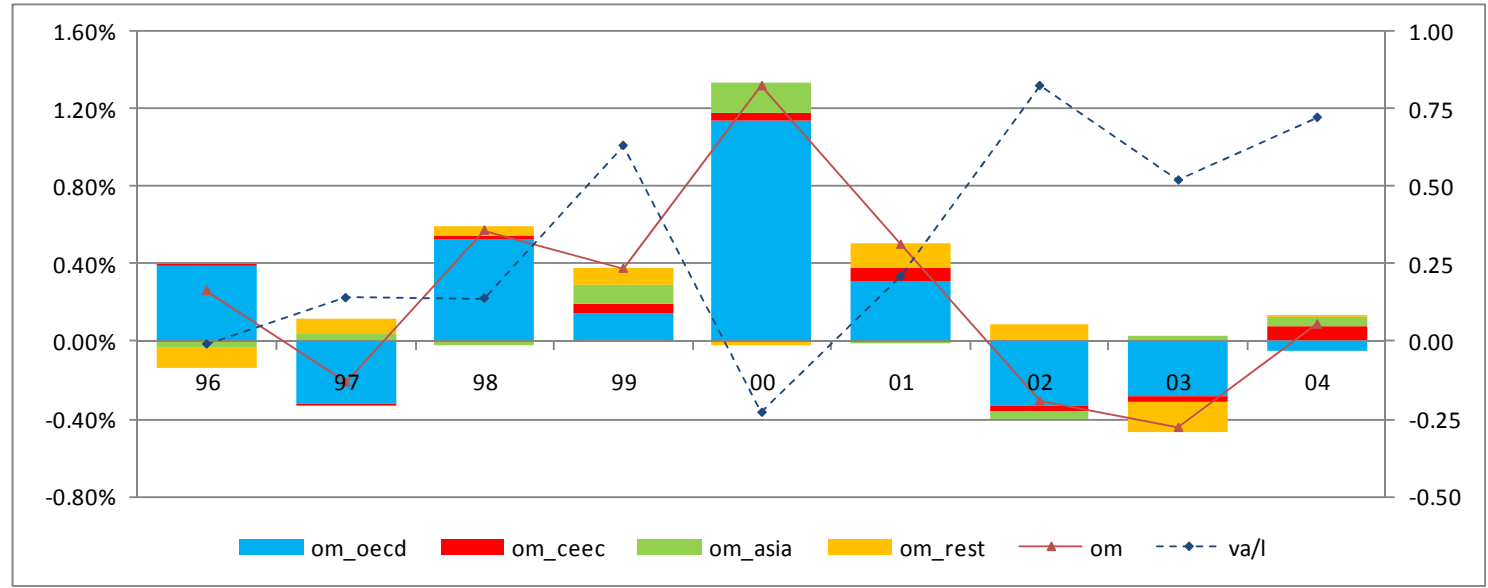

Source: own calculations

Graph A4 Year-on-year variations in value-added per hour worked (va/l - RHS) and regional and overall business services offshoring (os, os_oecd, os_ceec, os_asia, os_rest - LHS) in market services

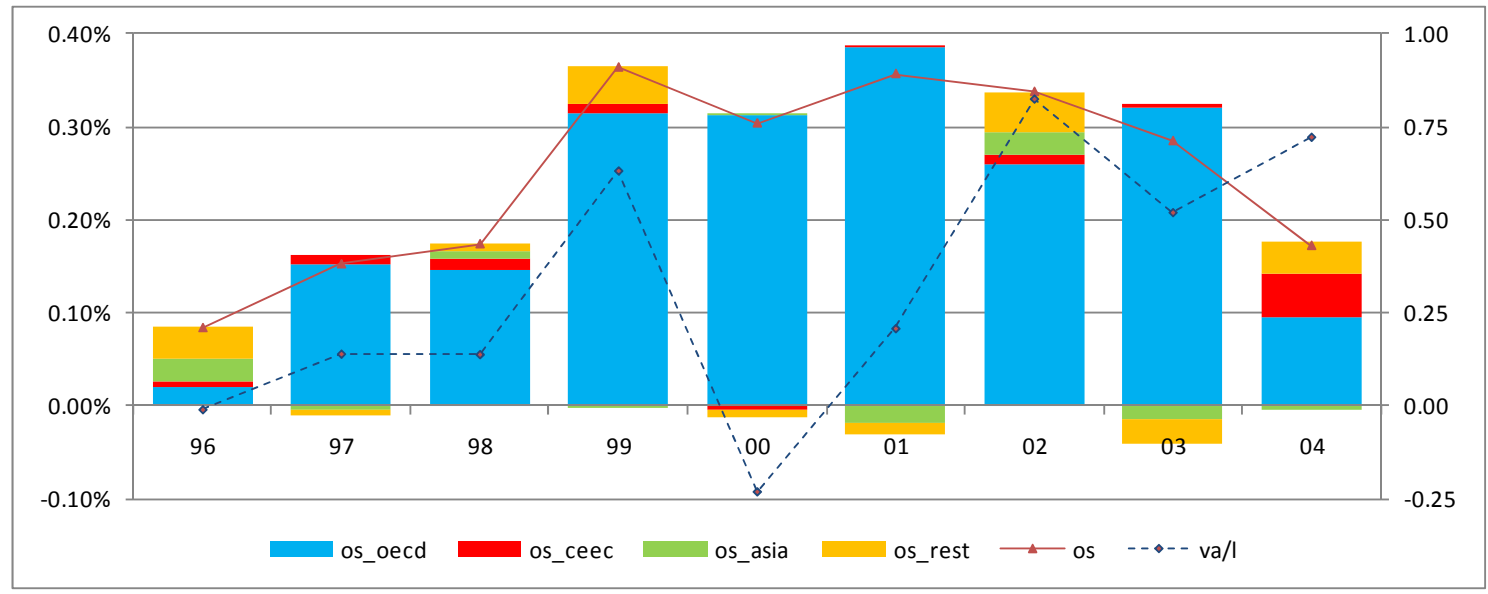

Source: own calculations 
Graph A5 Average annual growth rates over 1995-2004 of value-added per hour worked (va/l vertical axis) and materials offshoring (om - horizontal axis) in 63 manufacturing industries

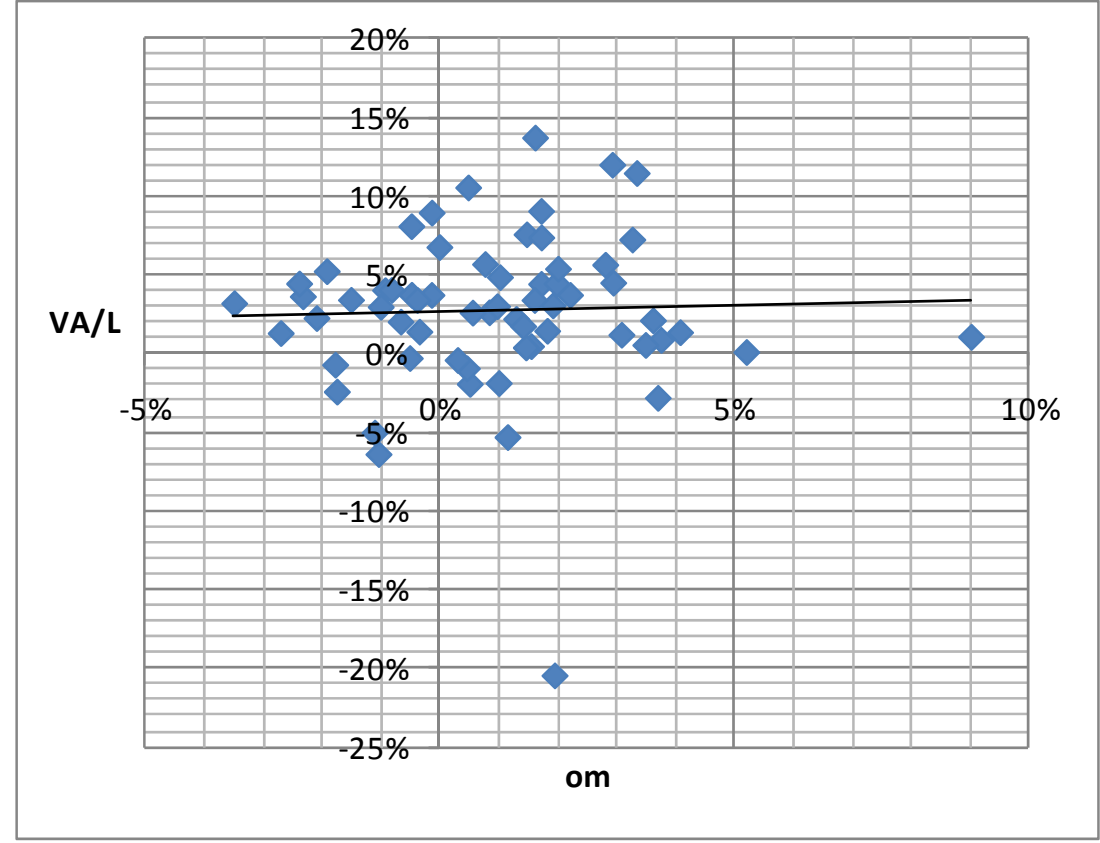

Source: own calculations

Graph A6 Average annual growth rates over 1995-2004 of value-added per hour worked (va/l vertical axis) and business services offshoring (os - horizontal axis) in 63 manufacturing industries

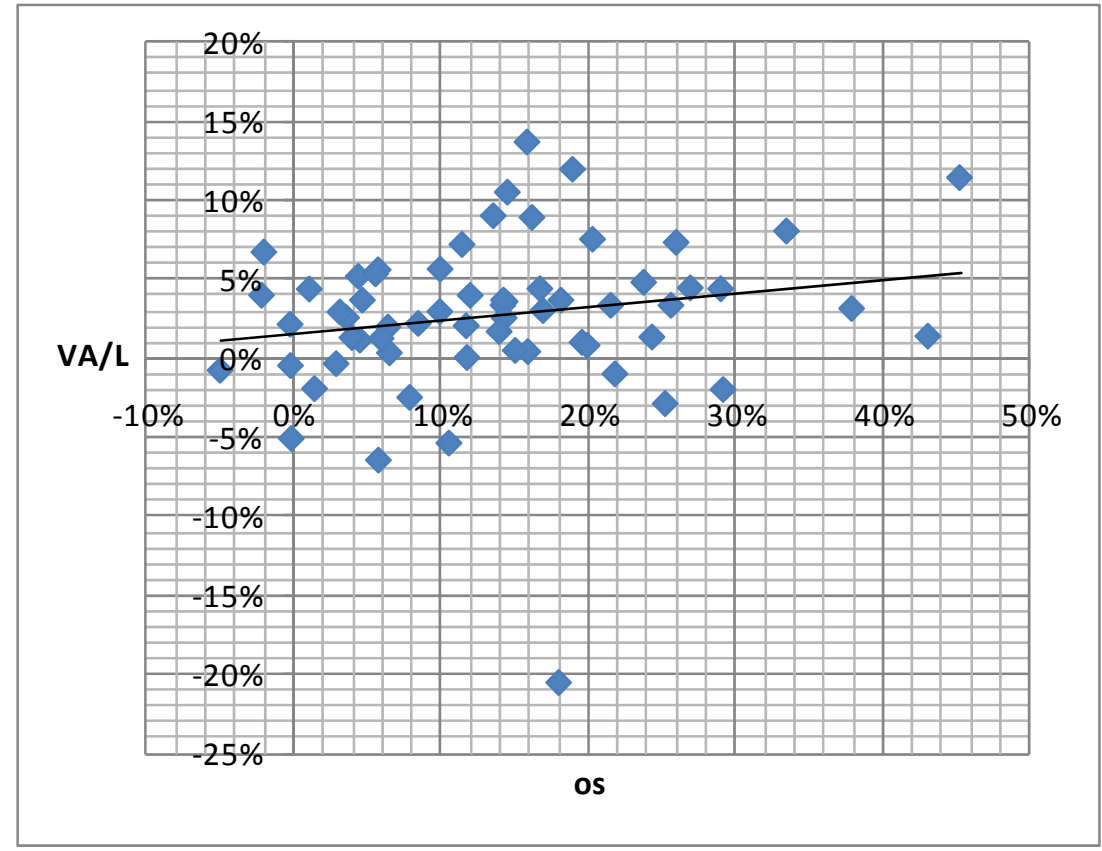

Source: own calculations 
Graph A7 Average annual growth rates over 1995-2004 of value-added per hour worked (va/l vertical axis) and materials offshoring (om - horizontal axis) in $\mathbf{4 0}$ market service industries

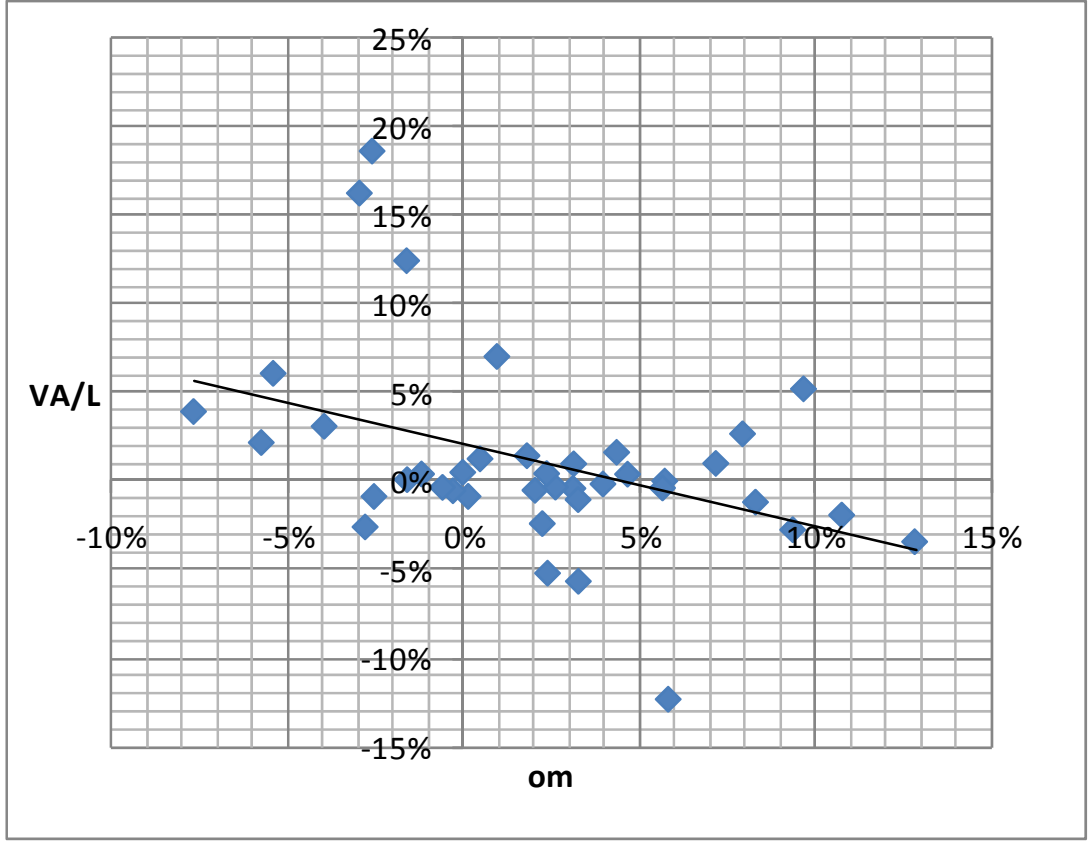

Source: own calculations

Graph A8 Average annual growth rates over 1995-2004 of value-added per hour worked (va/l vertical axis) and business services offshoring (os - horizontal axis) in $\mathbf{4 0}$ market service industries

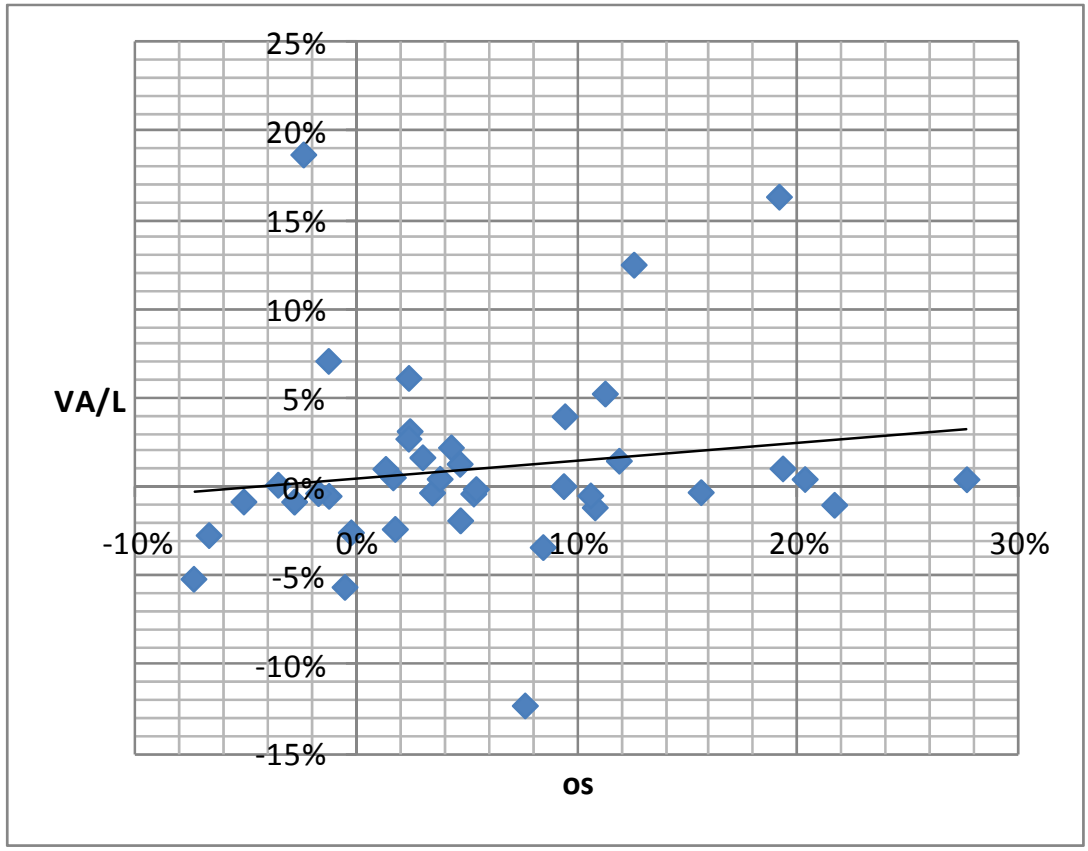

Source: own calculations 
Table A4 Estimation results for labour productivity (value-added per hour worked) with total and regional offshoring intensities in manufacturing

\begin{tabular}{|c|c|c|c|c|}
\hline & Total & OECD & CEEC & ASIA \\
\hline \multirow[t]{2}{*}{ Capital-labour ratio } & 0.0569 & 0.0599 & 0.0339 & 0.0250 \\
\hline & $(0.202)$ & $(0.202)$ & $(0.213)$ & $(0.203)$ \\
\hline \multirow[t]{2}{*}{ Materials offshoring } & $1.048^{\star \star}$ & & & \\
\hline & $(0.406)$ & & & \\
\hline \multirow[t]{2}{*}{ Services offshoring } & $6.066^{\star \star \star}$ & & & \\
\hline & $(1.711)$ & & & \\
\hline \multirow[t]{2}{*}{ Materials offshoring to OECD } & & $0.979 * \star \star$ & & \\
\hline & & $(0.359)$ & & \\
\hline \multirow[t]{2}{*}{ Services offshoring to OECD } & & $6.744^{\star \star \star}$ & & \\
\hline & & $(1.784)$ & & \\
\hline \multirow[t]{2}{*}{ Materials offshoring to CEEC } & & & -1.826 & \\
\hline & & & $(2.491)$ & \\
\hline \multirow[t]{2}{*}{ Services offshoring to CEEC } & & & 60.23 & \\
\hline & & & $(74.63)$ & \\
\hline \multirow[t]{2}{*}{ Materials offshoring to ASIA } & & & & 2.116 \\
\hline & & & & $(1.508)$ \\
\hline \multirow[t]{2}{*}{ Services offshoring to ASIA } & & & & $173.7^{*}$ \\
\hline & & & & $(97.19)$ \\
\hline Observations & 567 & 567 & 567 & 567 \\
\hline R-squared & 0.17 & 0.16 & 0.13 & 0.14 \\
\hline
\end{tabular}

Source: own calculations

Remarks: 63 manufacturing industries covered; ordinary least squares estimations in differences for value-added per hour worked; all equations include time and industry dummies; value-added per hour worked and capitallabour ratio in natural logs; robust standard errors reported in parentheses; $\mathrm{N}$ : number of observations; R-sq: R-squared; * $p<0.1,{ }^{* *} p<0.05,{ }^{* \star *} p<0.01$. 
Table A5 Estimation results for labour productivity (value-added per hour worked) with total and regional offshoring intensities in market services

\begin{tabular}{|c|c|c|c|c|}
\hline & Total & OECD & CEEC & ASIA \\
\hline \multirow[t]{2}{*}{ Capital-labour ratio } & $0.352^{*}$ & $0.338^{*}$ & $0.363^{\star \star}$ & $0.377^{* \star}$ \\
\hline & $(0.181)$ & $(0.177)$ & $(0.175)$ & $(0.177)$ \\
\hline \multirow[t]{2}{*}{ Materials offshoring } & -0.588 & & & \\
\hline & $(0.547)$ & & & \\
\hline \multirow[t]{2}{*}{ Services offshoring } & $2.533^{\star \star \star}$ & & & \\
\hline & $(0.903)$ & & & \\
\hline \multirow[t]{2}{*}{ Materials offshoring to OECD } & & -0.645 & & \\
\hline & & $(0.594)$ & & \\
\hline \multirow[t]{2}{*}{ Services offshoring to OECD } & & $2.687^{\star \star \star}$ & & \\
\hline & & $(0.973)$ & & \\
\hline \multirow[t]{2}{*}{ Materials offshoring to CEEC } & & & -1.604 & \\
\hline & & & $(3.556)$ & \\
\hline \multirow[t]{2}{*}{ Services offshoring to CEEC } & & & 22.09 & \\
\hline & & & $(39.66)$ & \\
\hline \multirow[t]{2}{*}{ Materials offshoring to ASIA } & & & & -1.204 \\
\hline & & & & $(2.446)$ \\
\hline \multirow[t]{2}{*}{ Services offshoring to ASIA } & & & & $37.82^{*}$ \\
\hline & & & & $(22.06)$ \\
\hline Observations & 360 & 360 & 360 & 360 \\
\hline R-squared & 0.25 & 0.25 & 0.23 & 0.23 \\
\hline
\end{tabular}

Source: own calculations

Remarks: 40 market services industries covered; ordinary least squares estimations in differences for value-added per hour worked; all equations include time and industry dummies; value-added per hour worked and capitallabour ratio in natural logs; robust standard errors reported in parentheses; N: number of observations; R-sq: R-squared; * $p<0.1,{ }^{* *} p<0.05,{ }^{* * *} p<0.01$. 